\title{
EFEITOS DE DIFERENTES COBERTURAS MORTAS OBTIDAS APARTIR DO MANEJO MECÂNICO COM ROÇADEIRA LATERAL NA DINÂMICA POPULACIONAL DE PLANTAS DANINHAS EM CITROS
}

\author{
Hector Alonso San Martin Matheis
}

\author{
Dissertação apresentada à Escola Superior de Agricultura \\ “Luiz de Queiroz”, Universidade de São Paulo, para obtenção \\ do título de Mestre em Agronomia, Área de Concentração: \\ Fitotecnia.
}

P I R A C I C A B A

Estado de São Paulo - Brasil

Abril - 2004 


\title{
EFEITOS DE DIFERENTES COBERTURAS MORTAS OBTIDAS APARTIR DO MANEJO MECÂNICO COM ROÇADEIRA LATERAL NA DINÂMICA POPULACIONAL DE PLANTAS DANINHAS EM CITROS
}

\author{
Hector Alonso San Martin Matheis \\ Engenheiro Agrônomo
}

Orientador: Prof. Dr. RICARDO VICTORIA FILHO

Dissertação apresentada à Escola Superior de Agricultura

"Luiz de Queiroz”, Universidade de São Paulo, para obtenção do título de Mestre em Agronomia, Área de Concentração: Fitotecnia.

P I R A C I C A B A

Estado de São Paulo - Brasil

Abril - 2004 


\section{Dados Internacionais de Catalogação na Publicação (CIP)}

DIVISÃO DE BIBLIOTECA E DOCUMENTAÇÃO - ESALQ/USP

\section{San Martin Matheis, Hector Alonso}

Efeitos de diferentes coberturas mortas obtidas a partir do manejo mecânico com roçadeira lateral na dinâmica populacional de plantas daninhas em citros I Hector Alonso San Martin Matheis. - - Piracicaba, 2004.

$68 \mathrm{p}$.

Dissertação (mestrado) - - Escola Superior de Agricultura Luiz de Queiroz, 2004.

Bibliografia.

1. Adubação 2. Adubo verde 3. Cobertura morta 4. Fruta cítrica 5. Planta daninha 6. Roçadora I. Título

CDD 632.58

\section{"Permitida a cópia total ou parcial deste documento, desde que citada a fonte - $\mathrm{O}$ autor"}




\section{OFREZCO}

A Dios, único. Criador del Universo, fuente de todo el bien y el poder, sin el nada existiría.

A Santa Maria, Madre de Dios, Inmaculada e Intercesora nuestra, por todo que me ha protegido y por ampararme en los momentos mas difíciles de mi existencia.

A mi abuelita Carmen que infelizmente no esta mas entre nosotros. "Existe mucha añoranza, pero el recuerdo de su presencia y el sonido de su voz, soplan suavemente en nuestra memoria”.

A mis papas Abel y Rita que me dieron la vida y me enseñaron a vivirla con dignidad; iluminaron mis caminos con afecto y dedicación, para que los enfrentara sin miedo y lleno de esperanza; y que se entregaron enteros renunciando a sus sueños, para que muchas veces pudiera realizar los míos.

A mi hermanos Maria del Carmen e Ignácio que siempre me apoyaron para que emprendiera esta aventura. A toda mi família por el apoyo recibido, para que continuara subiendo un escalon mas. 


\section{AGRADECIMENTOS}

Ao Prof. Dr. Ricardo Victoria Filho pela, dedicação e paciência na orientação e principalmente, pela amizade construída durante o programa de Mestrado;

A Escola Superior de Agricultura “Luiz de Queiroz” em especial à Coordenação do Curso de Pós-graduação em Fitotecnia pela oportunidade de realização do curso;

A CAPES (Coordenação de Aperfeiçoamento de Pessoal de Nível Superior) pela concessão da bolsa de Pós-graduação;

À empresa PIRAI, em especial ao Engenheiro José Aparecido Donizete Carlos pelas sementes dos diferentes adubos verdes utilizados nesta pesquisa, assim como a amizade e as sugestões para a realização do trabalho;

Àos professores do Departamento de Produção Vegetal da ESALQ/USP, pelos conhecimentos transmitidos e dedicação aos alunos;

Ao Dr. Roberto Arevalo pelo apoio e amizade e ao Dr. Ronaldo Coelho pelas análises estatísticas;

À Luciane Aparecida Lopes Toledo, secretaria do programa de Pós-graduação de Fitotecnia, pela paciência mostrada no inicio do mestrado e pela amizade e apoio;

Às secretarias do Departamento de Produção Vegetal da ESALQ/USP, Elizabete Zarkiz, Célia Rodrigues e a Sra. Helena Rodrigues, pela amizade e dedicação; 
Aos funcionários da área de Biologia e Manejo de plantas daninhas, Luiz Ferrari, Aparecido Mendes e Fernando Trimer, pelo auxilio e amizade durante o desenvolvimento dos trabalhos;

A todos os funcionários do Departamento de Produção Vegetal da ESALQ/USP pela colaboração e amizade;

Aos professores Dr Juan Lorenzo Medina Pitalua e Dr José Alfredo Dominguez Valenzuela pelo direcionamento e incentivo nos primeiros passos profissionais da minha vida;

Ao Sr Dario Corrêa e Dona Mavi (In Memoriam) por terem-me aberto as portas da sua casa e me brindando um apoio incondicional (Meus pais brasileiros);

A minha família venezuelana (Jesus, Beatriz, Fernando e Estefania) pelos momentos compartilhados, pela amizade construída e a confiança depositada em mim;

A Kércya, por seu ilimitado apoio, bem como o carinho e compreensão mostrada durante essa etapa da minha vida;

Aos colegas e amigos Renan, Fábio (Touchê), Guillermo, Daniela, Alejandro, Esteban, Luciane, Evandro, Suguitani, Adriana, Carlos, Oscar, Marta, Mariutzi, Patrícia, Fernando (Gambe), Marcelo (Brega), Sally, Ruben, Saulo, Juan (Peruano), Edgar, Ebert, a amizade, companheirismo e apoio nos momentos difíceis;

Aos integrantes da República SIVIÉ - PIRA: Júnior (Kumprido), Gustavo, Fernando, Niceu e Juan pelos momentos de alegria que desfrutamos;

E as todas as pessoas que contribuíram direta ou indiretamente para a realização deste trabalho. 
As nuvens mudam sempre de posição, mas são sempre nuvens no céu. Assim devemos ser todo dia, mutantes, porém leais com o que pensamos e sonhamos; lembre-se, tudo se desmancha no ar, menos os pensamentos (Paulo Beleki). 


\section{SUMÁRIO}

Página

LISTA DE TABELAS ................................................................ ix

RESUMO........................................................................ Xiv

SUMMARY .......................................................................... Xvi

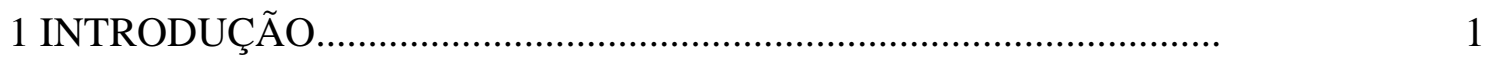

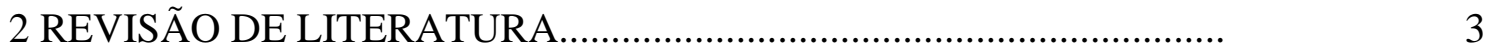

2.1 Importância da citricultura no Brasil e no mundo ............................ 3

2.2 Interferência das plantas daninhas à cultura de citros............................ 4

2.3 Perdas ocasionadas pelas plantas daninhas e épocas de controle........................................................................

2.4 Métodos de controle de plantas daninhas em citros...........................

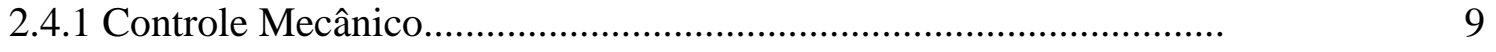

2.4.2 Controle Cultural...............................................................

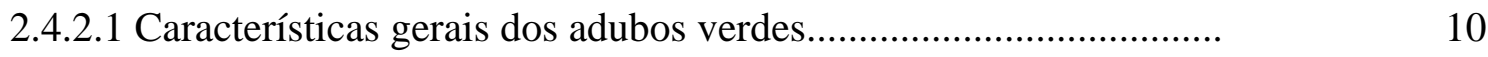

2.4.2.2 Efeito de adubos verdes sobre a fertilidade do solo........................ 10

2.4.2.3 Efeito de adubos verdes sobre plantas daninhas.......................... 17

2.4.2.4 Efeito da cobertura morta na população de plantas daninhas......... 18

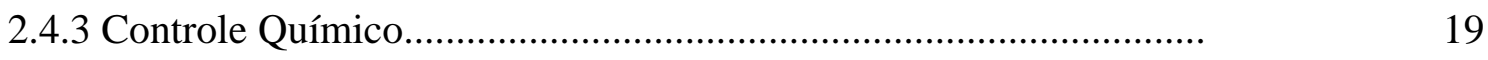


2.5 Manejo integrado de plantas daninhas em citros............................... 20

3. MATERIAIS E MÉTODOS........................................................... 24

3.1 Experimento 1: Manejo mecânico de diferentes coberturas vegetais num pomar em produção..............................................................

3.2 Experimento 2: Manejo mecânico de diferentes vegetações num pomar em formação.....................................................................

3.3 Experimentos em casa de vegetação..................................................

4 RESULTADOS E DISCUSSÕES....................................................

4.1 Experimento 1: Manejo mecânico de diferentes coberturas vegetais num pomar em produção..................................................................

4.2 Experimento 2: Manejo mecânico de diferentes vegetações num pomar em formação...................................................................... 


\section{LISTA DE TABELAS}

Página

01 Dados pluviométricos e temperaturas mensais (durante os meses de condução dos ensaios). Piracicaba, S.P. 2003 - USP/ ESALQ..

02 Análise química do solo da área experimental. Piracicaba, S.P.

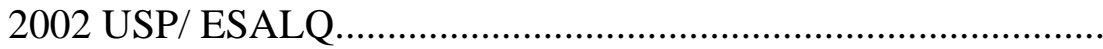

03 Tratamentos utilizados no experimento com manejo mecânico de diferentes coberturas vegetais num pomar em produção Piracicaba, S.P. 2003 - USP/ ESALQ...............................................

04 Análise química do solo da área experimental. Piracicaba, S.P. 2002 - USP/ ESALQ.

05 Descrição dos fatores utilizados no delineamento fatorial 7 x 5 . Experimentos 1 e 3 na casa de vegetação com a utilização de coberturas vegetais para verificar o efeito nas plantas daninhas em condições de pós e pré-emergência. Piracicaba, S.P. 2003, USP/ ESALQ 
06 Descrição dos fatores utilizados no delineamento fatorial 5 x 4 . Experimentos 1 e 3 na casa de vegetação com a utilização de coberturas vegetais para verificar o efeito nas plantas daninhas em condições de pós e pré-emergência. Piracicaba S.P. 2003,

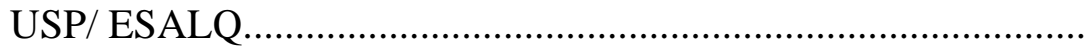

07 Médias da densidade de plantas daninhas (plantas $/ \mathrm{m}^{2}$ ) Determinações realizadas aos 30, 60, 90, 180 e 210 dias após a roçagem das diversas coberturas. Piracicaba, S.P. 2003 USP/ESALQ

08 Quantidade de fitomassa verde $\left(\mathrm{g} / \mathrm{m}^{2}\right)$ depositada pela roçadeira lateral na linha da cultura. Piracicaba, S.P. 2003 - USP/ESALQ.

09 Espécies predominantes de plantas daninhas encontradas nas diferentes coberturas aos 210 dias após da aplicação dos tratamentos. Valores médios de três repetições. Piracicaba, S.P. 2003 - USP/ESALQ.

10 Médias de densidade de plantas daninhas (plantas $/ \mathrm{m}^{2}$ ) Determinações realizadas aos 30, 60, 90, 180 e 210 dias após a roçagem das diversas coberturas. Piracicaba, S.P. 2003 -

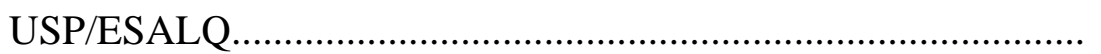

11 Porcentagem de área coberta de plantas daninhas nas diferentes coberturas aos 210 dias. Piracicaba, S.P. 2003 - USP/ESALQ..... 
12 Valores médios de determinações químicas do solo em duas profundidades (0-10 e 10-20 cm) em pomar de laranjeira 'Pêra'.

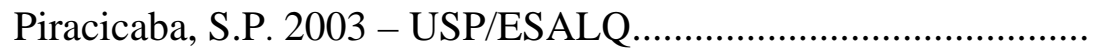

13 Valores médios para cálcio na profundidade de $10-20 \mathrm{~cm}$ em pomar de laranja ‘Pêra’. Piracicaba, S.P. 2003 - USP/ESALQ.....

14 Médias da densidade de plantas daninhas (plantas $/ \mathrm{m}^{2}$ ) Determinações realizadas aos 30, 60, 90, 180 e 210 dias após a roçagem das diversas coberturas. Piracicaba, S.P. 2003 -

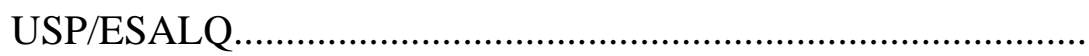

15 Quantidade de fitomassa verde $\left(\mathrm{g} / \mathrm{m}^{2}\right)$ depositada pela roçadeira lateral na linha da cultura. Piracicaba, S.P. 2003 - USP/ESALQ.

16 Porcentagem de área coberta por plantas daninhas nas diferentes coberturas mortas aos 210 dias. Piracicaba, S.P. 2003 -

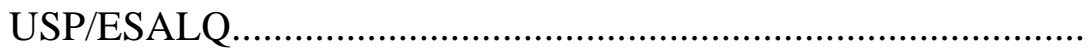

17 Médias de densidade de plantas daninhas (plantas/vaso) na avaliação realizada aos 30 dias após a instalação do experimento. Experimento 1 em casa de vegetação. Piracicaba, S.P. 2003 - USP/ESALQ.

18 Médias de produção de biomassa seca de plantas daninhas (g/vaso) em função da cobertura na avaliação realizada aos 30 dias após a instalação do experimento. Experimento 1 em casa de vegetação. Piracicaba, S.P. 2003 - USP/ESALQ..................... 
19 Médias de produção de biomassa seca (g/vaso) de plantas daninhas na avaliação realizada aos 30 dias após a instalação do experimento. Experimento 1 em casa de vegetação. Piracicaba,

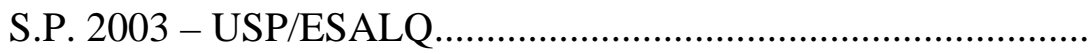

20 Médias de densidade de plantas daninhas (plantas/vaso) na avaliação realizada aos 30 dias após a instalação do experimento. Experimento 2 em casa de vegetação. Piracicaba, S.P. 2003 - USP/ESALQ

21 Médias de densidade de plantas daninhas (plantas/vaso) na avaliação realizada aos 30 dias após a instalação do experimento. Experimento 2 em casa de vegetação. Piracicaba,

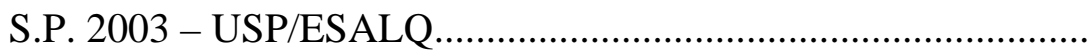

22 Médias de produção de biomassa seca (g/vaso) de plantas daninhas na avaliação realizada aos 30 dias após a instalação do experimento. Experimento 2 em casa de vegetação. Piracicaba,

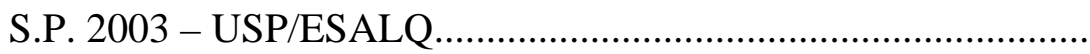

23 Médias de produção de biomassa seca de plantas daninhas (g/vaso) na avaliação realizada aos 30 dias após a instalação do experimento. Experimento 2 em casa de vegetação. Piracicaba, S.P. 2003 - USP/ESALQ 
24 Médias de densidade de plantas daninhas (plantas/vaso) na avaliação realizada aos 30 dias após a instalação do experimento. Experimento 3 em casa de vegetação. Piracicaba, S.P. 2003 - USP/ESALQ....................................................

25 Médias de produção de biomassa seca de plantas daninhas (g/vaso) na avaliação realizada aos 30 dias após a instalação do experimento. Experimento 1 em casa de vegetação. Piracicaba, S.P. 2003 - USP/ESALQ.

26 Médias de produção de biomassa seca de plantas daninhas (g/vaso) na avaliação realizada aos 30 dias após a instalação do experimento. Experimento 1 em casa de vegetação. Piracicaba, S.P. 2003 - USP/ESALQ.

27 Médias de densidade de plantas daninhas (plantas/vaso) na avaliação realizada aos 30 dias após a instalação do experimento. Experimento 4 em casa de vegetação. Piracicaba, S.P. 2003 - USP/ESALQ ......................................................

28 Médias de produção de biomassa seca de plantas daninhas (g/vaso) na avaliação realizada aos 30 dias após a instalação do experimento. Experimento em casa de vegetação. Piracicaba, S.P. 2003 - USP/ESALQ. 


\title{
EFEITOS DE DIFERENTES COBERTURAS MORTAS OBTIDAS APARTIR DO MANEJO MECÂNICO COM ROÇADEIRA LATERAL NA DINÂMICA POPULACIONAL DE PLANTAS DANINHAS EM CITROS
}

\author{
Autor: HECTOR ALONSO SAN MARTIN MATHEIS \\ Orientador: Prof. Dr. RICARDO VITÓRIA FILHO
}

\section{RESUMO}

Com o objetivo de avaliar o efeito da cobertura morta, produzida pelos adubos verdes lab-lab (Dolichos lablab L.), guandu-anão (Cajanus cajan (L.) Millsp), crotálaria (Crotalaria juncea L.), guandu (Cajanus cajan (L.) Millsp), milheto (Pennisetum glaucum (L.) Leeke), uma mistura de três coberturas (D. lablab + C. cajan + C. juncea), e a infestação natural do pomar de laranja, composta principalmente por capim-colonião (Panicum maximum Jacq.), sobre as plantas daninhas, bem como avaliar o efeito destas coberturas sobre as seguintes plantas daninhas: poaia (Richardia brasiliensis Gomes.), capim-colonião, erva-palha (Blainvillea biaristata DC.), falsa-serralha (Emilia sonchifolia (L.) DC.), capim-colchão (Digitaria horizontalis (Retz.) Koel.), corda-deviola (Ipomea grandifolia (Dammer.) O’Donell), picão-preto (Bidens pilosa L.), guanxuma (Sida santaremnensis H. Monteiro.) e tiririca (Cyperus rotundus (L.) Pers.), em condições de pós e pré-emergência, foram instalados dois experimentos em condições de campo e quatro em condições de casa de vegetação, na Escola Superior de Agricultura "Luiz de Queiroz", Universidade de São Paulo, Departamento de Produção Vegetal, Piracicaba, S.P. O delineamento experimental foi de blocos casualizados para um 
experimento em campo e blocos casualizados no esquema fatorial para os demais. O manejo mecânico das diferentes vegetações, foi realizado mediante a utilização de roçadeira lateral, marca KAMAQ, modelo NINJA MAC 260 que esta desenhada para projetar o material verde cortado, sobre a projeção da copa da árvore cítrica, formando dessa maneira uma camada de cobertura morta. Os parâmetros avaliados durante a condução dos experimentos, foram os seguintes: avaliações de contagem da infestação de plantas daninhas por vaso e ou por $\mathrm{m}^{2}$ (densidade), determinações de algumas propriedades químicas do solo e avaliações de produção de biomassa das plantas daninhas. Pelos dados obtidos nas condições locais dos experimentos conduzidos pode-se observar que: a utilização de coberturas mortas produzidas pelas distintas vegetações contribui, significativamente, na redução das populações das plantas daninhas, sendo os melhores resultados obtidos com a vegetação natural e a mistura dos adubos verdes; e que a adubação em área total, independentemente da cobertura vegetal utilizada apresenta uma menor densidade de plantas daninhas nas linhas das plantas cítricas. Sendo assim pode se concluir que a utilização de adubos verdes pode contribuir de maneira significativa na redução da comunidade infestante, auxiliando de forma sustentável o manejo integrado de plantas daninhas; além de contribuir com outros benefícios inerentes a utilização dessa prática. 


\title{
MULCHES EFFECT PRODUCED THROUGH MECHANICAL MANAGEMENT WITH A LATERAL ROTARY MOWER ON THE POPULATION DYNAMICS OF WEEDS ON CITRUS
}

\author{
Author: HECTOR ALONSO SAN MARTIN MATHEIS \\ Adviser: Prof. Dr. RICARDO VITÓRIA FILHO
}

\section{SUMMARY}

With the objective of evaluating the effect of the mulches produced by the cover crop Dolichos lablab, Cajanus cajan, Crotalaria juncea, Pennisetum glaucum, a mixture of three cover crops (Dolichos lablab + Cajanus cajan + Crotalaria juncea), and a natural infestation in orange tree plantations composed mostly by Panicum maximum on weeds and to evaluate the effect of these cover crop on the following weeds Richardia brasiliensis, Panicum maximum, Blainvillea biaristata, Emilia sonchifolia, Digitaria horizontalis, Ipomea grandifolia, Bidens pilosa, Sida santaremnensis and Cyperus rotundus, in conditions of pos and pre-emergence, two experiments in field conditions and four in greenhouse conditions were carried out at the Superior School of Agricultura "Luiz of Queiroz", University of São Paulo, Plant Production Department, São Paulo, Piracicaba - SP - Brazil. The experimental design used was of randomized blocks for an experiment in the field and randomized blocks in the factorial design for the others. The mechanical management of the different crops was carried out utilizing a KAMAQ lateral rotary mower Ninja Mac 260, designed to throw the cut crops down forming a layer of mulch around the citric plant. The data collected during the experiments were $\mathrm{planta} / \mathrm{m}^{2}$ and plant/pot density, determination of some chemical conditions of the soil and weed dry biomass production in g/pot. In the carried out experiments, it could be 
observed that the use of mulches produced by different crops contributes significantly to reduce weeds. The best results were obtained in a natural infestation and the mixture of three cover crops. The fertilization in the whole area regardless the cover crops, presents a minor density of weeds in the lines of the citric plants. Furthermore, it can be concluded that the use of cover crops contributes widely to reduce weeds, supporting integrated management of weeds and providing with other inherent benefits. 


\section{INTRODUÇÃO}

As plantas cultivadas dependem de vários fatores ambientais para completar seu ciclo e muitos destes, influenciam sobremaneira a sua potencialidade produtiva.

A cultura dos citros está sujeita à ação de vários fatores abióticos e bióticos que afetam direta ou indiretamente sua rentabilidade agrícola. Dentre esses fatores, tem grande importância a interferência das plantas daninhas.

O manejo de plantas daninhas torna-se indispensável, principalmente quando se trata de uma cultura perene, que exige alto investimento e, conseqüentemente, altas produtividades, de forma que isso venha a proporcionar retornos financeiros compensatórios. Nas condições tropicais e subtropicais, o uso freqüente da grade e de herbicidas aplicados em pré-emergência, expõem o solo à ação direta das chuvas e ventos. A compactação e a erosão têm motivado alguns estudos de campo para avaliar alternativas de manejo do mato nas linhas e entrelinhas da cultura, com o uso de coberturas vegetais para minimizar as perdas, explorando com mais racionalidade os próprios recursos naturais (Carvalho, et al., 2001).

Em cultivos perenes, quando o controle das plantas daninhas é realizado nas linhas de plantio, normalmente tem-se o objetivo de minimizar a interferência com a cultura principal e evitar o crescimento das plantas de grande porte ou trepadeiras que podem afetar operações de controle de pragas e a colheita.

As plantas daninhas podem interferir diretamente no crescimento e na produção das plantas cítricas por competirem por recursos essenciais ao crescimento e liberarem substâncias alelopáticas (Blanco \& Oliveira, 1978; Singh \& Achhireddy, 1987) e, indiretamente, por atuarem como hospedeiras intermediárias de pragas e patógenos (Chiavegato, 1986; Leite Júnior \& Mohan, 1990). 
Em áreas onde é deixada uma fitomassa na superfície do solo, a infestação de plantas daninhas é afetada por fatores físicos, químicos e biológicos. Dentre os fatores físicos destaca-se a dificuldade da emergência da planta daninha, que apresenta poucas reservas em suas sementes para atravessar a camada de fitomassa, e a dormência das sementes que necessitam de luz para germinarem. A produção de inibidores bioquímicos, diretamente pelos restos vegetais ou pelos microrganismos, que se desenvolvem durante seu processo de decomposição, pode também inibir a germinação e a emergência de algumas espécies.

Atualmente, a pressões econômicas, sociais e ecológicas, para limitar o uso de defensivos químicos nos sistemas de produção, estão impulsionando a pesquisa na busca de procedimentos alternativos, que promovam um menor impacto ambiental e social.

Desta forma, no presente trabalho, procurou-se estudar a influência dos adubos verdes lab-lab (Dolichos lablab L.), guandu-anão (Cajanus cajan L. Millsp), crotalária (Crotalaria juncea L.), guandu (Cajanus cajan L. Millsp), milheto (Pennisetum glaucum (L.) Leeke), e uma mistura de três coberturas (lab-lab + guandu + crotalária) e a infestação natural do pomar de laranja, composta principalmente por capim-colonião (Panicum maximum Jacq.), sobre a infestação natural de plantas daninhas.

O objetivo principal foi disponibilizar informações que possam ser utilizadas de maneira prática, no manejo de plantas daninhas, visando reduzir o uso de herbicidas e procurando contribuir positivamente para um desenvolvimento sustentável. 


\section{REVISÃO DE LITERARTURA}

\subsection{Importância da citricultura no Brasil e no mundo}

A citricultura é amplamente distribuída e economicamente importante nas regiões tropicais e subtropicais, onde as condições edáfoclimáticas são adequadas para o seu cultivo (Davies \& Albrigo, 1994). Dentre as frutas cítricas conhecidas, as laranjas correspondem a 64\% do volume da produção mundial (Neves \& Boteon, 1998). Entretanto, a distribuição das áreas é muito irregular ao redor do globo. De acordo com a FAO (2004) o Brasil e Estados Unidos da América do Norte detêm cerca de 35\% da produção mundial.

Os citros são as frutas mais produzidas no mundo, equivalendo a $24 \%$ da produção total, superando as culturas da uva, banana e maçã (ABECITRUS, 2003; FNP Consultoria \& Comércio, 2003).

A citricultura no Brasil é uma atividade agrícola das mais importantes, tanto pela renda gerada pelos seus produtos (mercado interno e externo) como também pelo seu valor social, sendo uma grande fonte geradora de emprego. Para o ano agrícola 2002/2003, a produção nacional foi estimada em mais de 370 milhões de caixas (40,8 kg), sendo o Estado de São Paulo responsável por cerca de 80\% deste total (ABECITRUS, 2003; FNP Consultoria \& Comércio, 2003).

Segundo Amaro \& Maia (1997), o desenvolvimento da citricultura, no Estado de São Paulo, é favorecido pelas condições climáticas favoráveis, pelo preço da terra, o custo da mão-de-obra e a garantia de mercado para as frutas cítricas. De acordo com Amaro et al. (1991) outras regiões possuem limitações climáticas para os citros como algumas áreas do Nordeste, onde as chuvas são inferiores a 700 mm por ano, e outras na região Sul, onde podem ocorrer geadas fortes. 
As boas condições climáticas do Estado de São Paulo, associadas ao uso de diferentes cultivares, permitiram à indústria local estender as suas operações por um período superior a 9 meses no ano (Viégas \& Guimarães, 1991), enquanto nos Estados Unidos da América do Norte e no México, concorrentes diretos do Brasil, o período de produção é de aproximadamente 6 meses, devido ao menor número de variedades plantadas e às condições climáticas (Neves, 1996).

Segundo Neves \& Boteon (1998), as indústrias de suco concentrado de laranja comercializam, anualmente, cerca de $85 \%$ da produção paulista. No mundo, a cada dez copos de suco de laranja consumidos, oito são de procedência brasileira, sendo o Estado de São Paulo responsável por 98\% da produção total. A produção de suco concentrado brasileiro é praticamente toda destinada à exportação, pois somente $2 \%$ da laranja processada ficam no mercado interno (Amaro \& Maia, 1997).

Dentre as laranjas doces cultivadas no Estado de São Paulo, a variedade 'Pêra'(Citrus sinensis (L.) Osbeck) é a principal, representando 43\% do total das laranjeiras existentes, ou seja, quase 97 milhões de árvores em formação e produção. Esta variedade ocupa lugar de destaque no total da produção destinada aos mercados interno e externo de frutas frescas como, por exemplo, para produção de suco, segmento em franca expansão no mercado interno, sendo que as indústrias processadoras de suco cítrico concentrado e congelado são as maiores consumidoras dos frutos desta variedade em São Paulo (FNP Consultoria \& Comércio, 2003).

\subsection{Interferência das plantas daninhas à cultura de citros}

A presença das plantas silvestres que emergem espontaneamente nos ecossistemas agrícolas pode condicionar uma série de fatores bióticos atuantes sobre as plantas cultivadas, que irão interferir não só na sua produtividade biológica, como na operacionalização do sistema empregado. Por isso, essas plantas recebem a denominação de plantas daninhas (Pitelli, 1985).

Os efeitos negativos observados no crescimento, desenvolvimento e produtividade de uma cultura, devido à presença das plantas daninhas, não devem ser atribuídos exclusivamente à competição imposta por estas últimas, mas sim, como 
resultante de um total de pressões ambientais diretas, como competição, alelopatia, interferência na colheita, e indiretas hospedando pragas, moléstias e nematóides. A esse efeito global denomina-se interferência. Assim, num sentido amplo, o termo refere-se ao conjunto de ações que recebe uma determinada cultura em decorrência da presença da comunidade infestante num determinado local. Especificamente em relação aos efeitos diretos sobre as plantas cultivadas, os mais importantes mecanismos de interferência são competição e alelopatia (Pitelli, 1985).

A competição que ocorre nas áreas cultivadas seja intraespecífica ou interespecífica, é um dos princípios básicos no relacionamento dos indivíduos nas comunidades florísticas, sendo que há muito tempo é conhecida pelo homem à necessidade de livrar as culturas da presença dessa interferência (Pitelli, 1985).

Os fatores que afetam o grau de interferência entre as plantas daninhas e as plantas cultivadas foram descritos em um esquema proposto por Bleasdale (1960), posteriormente adaptado por Blanco (1972) e Pitelli (1985). Segundo esse esquema, o grau de interferência depende de fatores ligados à própria cultura (espécie, espaçamento e densidade de plantio), à comunidade infestante (composição específica, densidade e distribuição) e às condições específicas em que ocorre a associação entre a cultura e a comunidade infestante, como às condições edáficas, climáticas e os tratos culturais. Além disso, depende também da época e da extensão do período em que ocorre a convivência entre as plantas daninhas e a cultura.

Um dos pontos básicos para a utilização adequada dos métodos de controle é o conhecimento das plantas daninhas com informações sobre a biologia, época de ocorrência e danos por elas produzidos às plantas de citros (Victoria Filho, 1998).

A presença da comunidade infestante em áreas agrícolas é função direita das condições de manejo do solo, da água e do clima que podem propiciar condições específicas para que determinadas espécies predominem (Gelmini, 1988).

É comum nas áreas citrícolas brasileiras encontrar pomares infestados por espécies agressivas que faziam parte do agroecossistema anterior, como ocorrem nas regiões onde as plantas cítricas foram instaladas sobre áreas de pastagens. As principais plantas daninhas que ocorrem nas áreas citrícolas são: capim-marmelada (Braquiaria 
plantaginea (Link.) Hitchc), capim-colonião (Panicum maximum Jacq.), capim-colchão (Digitaria horizontalis (Retz.) Koel.), capim-carrapicho (Cenchrus echinatus L.), capimpé-de-galinha (Eleusine indica (L.) Gaertn.), grama-seda (Cynodon dactylon (L.) Pers.), capim-favorito (Rhynchelitrum repens (Willd.) C.E. Hubb), capim-amargoso (Trichacne insularis (L.) Fedde.) grama-batatais (Paspalum notatum Flügge.), capim-braquiaria (Braquiaria decumbens Stapf.), tiririca (Cyperus rotundus L.), trapoeraba (Commelina spp.), picão-preto (Bidens pilosa L.), carrapicho-de-carneiro (Acanthospermum hispidum DC.), guanxuma (Sida spp.), caruru (Amaranthus spp.), falsa-serralha (Emilia sonchifolia (L.) DC.), erva-palha (Blainvillea biaristata DC.) mentrasto (Agerantum conyzoides L.), picão-branco (Galinsoga parviflora Cav.), corda-de-viola (Ipomea spp.), beldroega (Portulaca oleraceae L.), poaia-branca (Richardia brasiliensis Gomes.) e serralha (Sonchus oleraceus L.) (Victoria Filho et al., 1991).

Nas regiões tropicais as plantas daninhas representam uns dos mais graves problemas na produção de citros, já que competem por água, luz e nutrientes disponíveis no solo. Horowits (1973) verificou os efeitos competitivos da grama-seda, tiririca e capim-massambará (Sorghum halepense (L.) Pers.) em plantas jovens de laranja azeda, observando diminuição na altura da planta, diâmetro do tronco e no número de folhas após três a quatro meses, principalmente em tiririca, seguida de capim-massambará e grama-seda. $\mathrm{O}$ autor ainda menciona a possibilidade de que parte dos prejuízos eram causados por substâncias eliminadas pelas raízes das plantas daninhas (alelopatia). Jordan (1983), trabalhando com laranja 'Valência', verificou a competição causada por caruru, buva (Conyza canadiensis (L.) Cronquist.), cardo (Circium vulgare (Savi) Ten.) e grama-seda, determinando como estas plantas afetaram o tronco, o crescimento da copa, o nível do nitrogênio das folhas, a produção e a qualidade dos frutos produzidos pela cultura. Os efeitos negativos dessas plantas daninhas sobre as laranjeiras foram relacionadas com a intensidade da competição. O controle das plantas daninhas reduziu essa interferência, proporcionalmente à quantidade de plantas controladas.

Perez \& Labrada (1986), em Cuba, conduziram um experimento durante um 18 meses, em plantações de tangerinas infestadas com grama-seda, em intensidade de infestação variando de 0, 5, 25, 50 e 100\% de cobertura do solo. No qual observaram 
que até $25 \%$ de infestação com a grama-seda o diâmetro do tronco, o crescimento da copa e altura das plantas citrícas não foram afetados. Na cobertura de 50\% houve uma redução no diâmetro do tronco, na copa e altura das plantas cítricas de 24, 27 e 14\% respectivamente. Enquanto na cobertura de 100\% ocorreu uma redução de 39, 51 e 40\% na mesmas variáveis analisadas. Os efeitos negativos foram evidentes após oito meses do estabelecimento da cobertura das plantas daninhas.

Tersi et al. (1999), conduziram um experimento num pomar de laranja 'Valência' com aproximadamente cinco anos de idade. Após quatro safras, constataram que não houve redução na altura das plantas de citros, onde não existiu controle de plantas daninhas. Somente na última safra estudada ocorreu diferença de produção entre os tratamentos, que consistiam na utilização de métodos mecânicos e químicos, bem como uma combinação entre eles no controle de plantas daninhas.

\subsection{Perdas ocasionadas pelas plantas daninhas e épocas de controle}

As perdas ocasionadas pelas plantas daninhas podem ser significativas. Nas condições subtropicais, Jordan (1983), determinou que a competição das plantas daninhas com as plantas cítricas reduz a área foliar e o rendimento da planta em 66\% e 63\%, no entanto nas condições tropicais de Cuba, Casamayor (1986) determinou uma redução do 78\%. De Negri (1996) observou perdas ao redor de 5\% ao ano; porém, Durigan (1996) relata que em áreas sem o manejo adequado das plantas daninhas as perdas variam de 20 a $40 \%$.

Procurando determinar as épocas e extensões dos períodos em que uma comunidade infestante provoca prejuízos à produção de um pomar de laranja 'Natal', com 6 anos de idade, em Limeira, SP, bem como observar os efeitos que o controle do mato, em diferentes épocas, acarreta sobre a densidade e a composição da flora daninha, Blanco \& Oliveira (1978) estudaram diferentes combinações de três períodos de manutenção ou controle do mato: abril a julho, agosto a novembro e dezembro a março. O mato presente no pomar de abril a julho não provocou prejuízos à produção, sendo que o controle deveria ser realizado de agosto a novembro ou de dezembro a março. A época de controle, após dois anos de condução do experimento, influenciou na 
capacidade de infestação das plantas daninhas. Com isso, concluíram que o mato pode ser deixado germinar com as primeiras chuvas de outubro, pois além de não haver perdas na produção, existe uma diminuição na população de plantas daninhas.

Carvalho et al. (1993), conduziram uma pesquisa na Bahia com o objetivo de determinar o período de interferência das plantas daninhas em um pomar de laranja 'Pêra', com 4 anos de idade, enxertadas sobre limão 'Cravo' (Citrus limonia (L.) Osbeck.). Os resultados obtidos, após quatro anos de estudo, levaram os autores a concluirem que o pomar deveria ser mantido livre da interferência das plantas daninhas de setembro até abril, abrangendo o período de deficiência hídrica no solo, que era de setembro a março.

O efeito da área de interferência das plantas daninhas no desenvolvimento inicial de tangerina 'Ponkan', enxertada sobre limão 'Cravo', foi avaliado por Bortolazzo (2002), no município de Piracicaba, SP. Os resultados mostraram que o controle com capinas em faixas permitiu melhor desenvolvimento das plantas cítricas em relação ao controle em coroamento, sendo que a capina de $25 \mathrm{~cm}$, em faixas, de cada lado do tronco, foi suficiente para garantir o adequado desenvolvimento das plantas cítricas, até o terceiro ano após a implantação.

\subsection{Métodos de controle de plantas daninhas em citros}

O manejo de plantas daninhas engloba métodos preventivos, erradicação e controle. Os métodos preventivos consistem em evitar a introdução e disseminação de plantas daninhas onde ainda não se manifestaram, tomando medidas como a limpeza de equipamentos, inspeção de mudas na aquisição e controle de plantas daninhas, nas áreas

próximas ao pomar. A erradicação consiste na eliminação de propágulos que possam formar novas plantas, sendo viável, devido ao seu alto custo, em pequenas reboleiras para evitar a propagação de espécies como a tiririca e grama-seda. Os métodos de controle visam reduzir a vegetação daninha de forma a não provocar danos econômicos (Instituto Agronômico do Paraná, 1992). 


\subsubsection{Controle Mecânico}

O controle mecânico, de acordo com Gelmini (1988), envolve capina manual, enxada rotativa e roçadeira. Para Petto Neto (1991) a capina manual é um método de controle de plantas daninhas que somente justifica sua utilização ao redor das plantas (coroas) ou em faixas laterais, em determinadas situações, como áreas declivosas e quando se tem mão de obra suficiente.

A enxada rotativa pulveriza o solo e aumenta muito a erosão. Tem menor rendimento que a grade e custo operacional maior. Promove disseminação de plantas daninhas e acentuado corte das raízes. É um implemento para ser utilizado superficialmente $(3 \mathrm{~cm}$ ), com plantas daninhas ainda pequenas (Durigan, 1994). Segundo Gelmini (1988), a enxada rotativa pode facilmente provocar ferimentos ao sistema radicular. Enquanto, Rodriguez (1991) relata que a capina com a enxada rotativa não deve ser considerada unicamente para o controle das plantas daninhas; também pode ser utilizada na incorporação lateral de adubos ao solo.

Gelmini (1988) cita que o uso de roçadeiras em culturas perenes e pastagens, principalmente em áreas de acentuado declive, nas entrelinhas, torna-se uma prática bastante utilizada e vantajosa. De acordo com Koller (1994) se as roçadas foram muito freqüentes, elas podem provocar o desaparecimento de algumas espécies, principalmente de folhas largas, e favorecer a predominância das gramíneas, principalmente as de ciclo perene e, em especial, gramíneas que tem propagação estolonífera, que são de difícil controle e mais prejudiciais aos citros por serem mais exigentes em nitrogênio e em água. A utilização de roçadeiras pode ser de grande valia para manter o ambiente dos pomares cítricos equilibrando e contribuindo inclusive para menor utilização de produtos químicos e diminuindo a compactação do solo (Rodríguez, 1991). 


\subsubsection{Controle Cultural}

\subsubsection{Características gerais dos adubos verdes}

Dominguez (1991) diz que a sustentabilidade de um agroecossitema tropical sujeito à condições de elevada temperatura e precipitação, demanda o manejo do solo mediante práticas de conservação e recuperação, sendo que uma destas práticas é o uso de adubos verdes. A adubação verde é uma prática conhecida desde a antigüidade, podendo ser definida como a incorporação ao solo de material vegetal não decomposto,

produzido ou não no local. Dessa operação, resultam alterações desejáveis no solo, em seus atributos químicos, levando a cultura principal a se beneficiar destas mudanças.

Os adubos verdes são plantas utilizadas com a finalidade de serem incorporadas ao solo fornecendo material orgânico, nitrogênio e outros nutrientes, com o intuito de melhorar as características físicas, químicas e biológicas dos solos cultivados.

A adubação verde, quando bem empregada, pode trazer vantagens tais como a cobertura do solo e, conseqüentemente, menor radiação solar direta; melhores condições físicas e biológicas do solo, devido ao maior aprofundamento das raízes; aumento no teor de matéria orgânica e nutrientes do solo; aumento do nitrogênio disponível, devido a fixação do nitrogênio atmosférico; e melhores condições para o controle de pragas e doenças (Instituto Agronômico do Paraná, 1985).

Quando se deseja um efeito significativo na utilização da adubação verde, é fundamental a freqüência de sua aplicação (Igue, 1984), sendo que para produzir satisfatoriamente, os solos deveriam ter no mínimo de 2 a 3\% de matéria orgânica (Gustafson, 1941; Thompson, 1952).

\subsubsection{Efeitos de adubos verdes sobre a fertilidade do solo}

Na fertilidade dos solos, a matéria orgânica é fundamental e, essencialmente, o objetivo da adubação verde é de prover biomassa vegetal (Bruce et al., 1991). Ao se empregar a adubação verde, o principal benefício obtido será a melhoria da fertilidade do solo pelo seu enriquecimento em matéria orgânica (Muzilli et al., 1989; Dominguez \& Medina, 2000), aumentando a capacidade de troca catiônica e liberando ácidos que atuam solubilizando materiais do solo; nas propriedades físicas, aumentando a 
capacidade de retenção da água, diminuindo com isso a lixiviação e melhorando a estrutura dos solos; e nas biológicas, propiciando, principalmente, condições favoráveis para a atividade microbiana do solo (Silva \& Chaves, 1966).

Em trabalho desenvolvido por Chaves (2000) foi demonstrado que ocorreu um aumento no teor da matéria orgânica quando se utilizou a adubação verde. Chaves \& Calegari, (2001), verificaram que a leucena (Leucaema leucephala Lam (De Witt)) comparada a adubação mineral na cultura do cafeeiro; após dez anos de estudo, provocou um acréscimo no teor de matéria orgânica, ocasionando aumento na CTC, que é um índice de melhoria da fertilidade do solo. Outros trabalhos científicos desenvolvidos comprovam o aumento da matéria orgânica pela utilização de adubação verde (Pavan et al., 1986; Chaves et al., 1997).

A adubação verde provoca uma série de alterações no solo, porém, uma das mais evidentes é no pH. Com o aumento da acidez, a disponibilidade de alguns nutrientes diminui e ocorre aumento de manganês e de elementos tóxicos como o alumínio e metais pesados (Pavan \& Chaves, 1998). A adição de resíduos de plantas, em geral diminui a acidez do solo. Este efeito, naturalmente, depende da quantidade de resíduos adicionados e da sua concentração em cátions básicos. Miyazawa et al. (1993) verificaram que os resíduos de espécies distintas de adubos verdes têm diferentes capacidades para aumentar o pH do solo e diminuir o teor de alumínio; as leguminosas causam maiores diminuições de acidez em relação às gramíneas e, por conseguinte, provocam maior neutralização do alumínio. De acordo com Chaves \& Calegari (2001) o efeito dos resíduos orgânicos sobre o pH é considerado temporário e de menor duração que a calagem convencional, no entanto, pode melhorar a fertilidade dos solos ácidos nos períodos críticos para as culturas.

Diversos estudos têm sido conduzidos com a finalidade de avaliar os efeitos na fertilidade do solo, proporcionados por diferentes espécies de coberturas vegetais.

Andrade et al. (1984) estudaram os efeitos da adubação verde e da incorporação dos resíduos da desfibragem de crotalária, sobre algumas características do solo, avaliando-se os efeitos na densidade aparente, porosidade total, teores de carbono, alumínio trocável, cálcio + magnésio trocável, potássio trocável e fósforo assimilável. 
Os autores concluíram que não houve efeito da adubação verde e da incorporação dos resíduos de desfiframento na porosidade total, nos teores de carbono, alumínio trocável, fósforo assimilável, potássio trocável e na atividade microbiana do solo. Entretanto houve aumento nos teores de cálcio + magnésio trocável, aos 90 dias após a incorporação.

Chagas et al. (1987), em Goiânia, em solo de cerrado, instalaram um experimento de adubação verde com crotalária, em consórcio com feijão comum (Phaseolus vulgaris L.), concluindo que a incorporação da crotalária não alterou o pH, a percentagem de matéria orgânica e os teores de alumínio, cálcio + magnésio, fósforo e potássio do solo, durante o desenvolvimento da cultura de feijão.

Vitti et al. (1979) procuraram verificar o efeito de cinco leguminosas sobre algumas características químicas de um latossolo vermelho amarelo fase arenosa. Após um ano da incorporação dos adubos verdes os autores observaram que o solo ainda não havia atingido o equilíbrio, mas havia ocorrido um aumento significativo no teor de matéria orgânica e na capacidade de troca catiônica.

A ciclagem de nutrientes promovida pelas leguminosas é fundamental para manter e acrescentar nutrientes nas camadas superficiais do solo, principalmente daqueles de fácil mobilidade como o cálcio, o magnésio e o potássio (Fávero \& Jucksch, 2000).

A utilização de crotalária como adubo verde promoveu o aumento da soma de bases (SB), da capacidade de troca de cátions efetiva (t), do teor de cálcio (Ca) e magnésio (Mg) na profundidade de 20 a $40 \mathrm{~cm}$ e reduziu a acidez potencial $(\mathrm{H}+\mathrm{Al})$ (Menegucci et al., 1995).

Fávero \& Jucksch (2000) conduziram um experimento em Sete Lagoas (MG), com o objetivo de avaliar os teores de macronutrientes entre leguminosas e plantas invasoras. Verificaram que, de forma geral, as plantas invasoras apresentam teores de P, $\mathrm{K}$ e Mg similares ou maiores que as leguminosas de adubação verde, evidenciando o potencial para ciclagem desses nutrientes.

Em trabalho desenvolvido por Silva (1995) em condições de campo, foi possível observar que o cultivo intercalar de adubos verdes em pomares de citros em formação 
durante quatro anos, contribui para a redução da aplicação de nitrogênio mineral e incrementou a reciclagem de nutrientes na formação do pomar.

As leguminosas podem fixar durante o período vegetativo, dependendo da espécie e condições do solo e clima, de zero a mais de $200 \mathrm{~kg} \mathrm{ha}^{-1}$ de nitrogênio. O aproveitamento pelas culturas que sucedem o adubo verde é de aproximadamente 12 a 25\% em solos argilosos (Derpsch, 1985). Quantidades maiores de nitrogênio fixado simbioticamente são observadas em leguminosas perenes, como é o caso de leucena, que chega a fixar até $400 \mathrm{~kg} \mathrm{ha}^{-1}$ ano (Kluthcouski, 1980).

Franco \& Shouto (1984) enfatizam que as leguminosas com sistema radicular profundo aumentam a eficiência de utilização dos adubos, uma vez que trazem às camadas superficiais do solo alguns nutrientes que seriam perdidos por lixiviação, principalmente $\mathrm{K}, \mathrm{Ca}, \mathrm{Mg}$ e $\mathrm{N}$, funcionando também como "agente minerador" dos nutrientes de reduzidas disponibilidades (P e Mo), tornando-os disponíveis às culturas principais.

Mello (1988) menciona que a mineralização do $\mathrm{N}$ dos adubos verdes (leguminosas), inicia-se quase imediatamente após a incorporação do material ao solo, devido à relação C:N. A velocidade de decomposição vai diminuindo à medida que a relação C:N vai se aproximando, tendendo para valores entre 10 e 12, que é a relação normal da matéria orgânica nos solos. De acordo com Tisdale \& Nelson (1975) em solos com relação C:N alta, inicialmente há um consumo de nitrato existente no solo, que é incorporado ao protoplasma dos microrganismos. A matéria orgânica perde carbono, que é convertido em $\mathrm{CO}_{2}$. A relação $\mathrm{C}: \mathrm{N}$ decresce e o processo todo resulta em uma imobilização líquida do nitrato do solo. Com a redução da relação C:N, surgem condições de mineralização, com liberação do amônio, que é logo convertido em nitrato.

A boa estrutura do solo contribui para o movimento adequado da água e do ar. A passagem abusiva de máquinas no pomar de citros ou a pulverização da camada arável por implementos agrícolas são prejudiciais à manutenção da estrutura adequada. A incorporação e/ou manutenção da matéria orgânica no solo é essencial para manter uma boa estrutura, além de contribuir para reduzir o risco de lixiviação de cátions, particularmente de potássio, em solos arenosos (Malavolta, 1976). 
Para Jones \& Embleton (1973), as funções primarias das leguminosas no pomar são: melhorar a estrutura do solo, impedir a erosão, melhorar as condições de fertilidade, tornando os nutrientes mais disponíveis, adicionar nitrogênio e remover o excesso de água. Segundo Scaranari \& Inforzato (1952) Crotalaria juncea apresenta grande resistência à seca, pois seu sistema radicular atinge até $4,6 \mathrm{~m}$, sendo que $80 \%$ dele se encontra nos primeiros $30 \mathrm{~cm}$ do solo. Gloria et al. (1980) relatam que C. juncea constitui-se no adubo verde com maior rendimento em material verde e de incorporação de $\mathrm{N}, \mathrm{P}_{2} \mathrm{O}_{5}$ e $\mathrm{K}_{2} \mathrm{O}$, quando comparada com mucuna-preta e soja cultivar Santa Rosa.

Devem ser escolhidas para essa prática espécies que produzam grande quantidade de matéria seca, que sejam resistentes ao ataque de pragas e doenças, que possuam sementes uniformes e de bom poder germinativo, que apresentem exigências relativamente baixas quanto ao preparo e fertilidade do solo e que tenham rápido crescimento, com sistema radicular profundo (Silva et al., 1999).

Deve haver coerência entre a idade das plantas de citros e o porte do adubo verde escolhido. No caso de pomares com plantas maiores, preferir adubos verdes como feijão-de-porco e guandu-anão, enquanto que nos mais novos tanto a crotalária quanto feijão guandu podem ser utilizados. Na existência de áreas com solos compactados, as espécies mais indicadas são aquelas de sistema radicular vigoroso, como o feijão guandu ou guandu-anão e nabo forrageiro. Geralmente, recomenda-se plantar em ruas intercaladas para que seja possível a execução dos tratos culturais dos citros; porém, há possibilidade de plantio em todas as ruas, intercalando-se espécies de diferentes portes, de modo que seja possível o trânsito de máquinas e trabalhadores. Como exemplo, pode-se citar a crotálaria x feijão-de-porco e o feijão guandu x feijão-de-porco, entre outros.

Embora os efeitos favoráveis dos adubos verdes sejam bem conhecidos não se deve pensar que estes possam aumentar permanentemente o teor de matéria orgânica no pomar. Proebsting (1952) não observou aumentos nos teores de matéria orgânica, de nitrogênio total e na capacidade de armazenamento de água do solo, depois de 25 anos da aplicação de adubos verdes. Entretanto, houve efeito favorável na velocidade de infiltração de água, conseqüência do melhoramento promovido na estrutura do solo. Tal 
melhoramento é causado pela ação dos microrganismos na matéria orgânica, que funciona como cimento das partículas do solo, o que leva à formação de agregados (Martin \& Waksman, 1941).

Algumas vantagens da utilização de outras famílias como adubos verdes, além das leguminosas, relacionam-se à elevada eficiência no rompimento de camadas compactadas; sistema radicular finamente dividido, portanto, possivelmente mais eficiente na absorção de nutrientes em ambientes pobres (Cintra \& Mielniczuk, 1983); elevada eficiência na reciclagem de fósforo (Clarkson, 1985); e maior estabilidade da cobertura morta, condição esta desejável em algumas situações, principalmente no caso das gramíneas cuja relação C:N é mais elevada que a das leguminosas.

A decomposição do material vegetal adicionado ao solo é um processo essencialmente biológico, sujeito portanto à interferência de inúmeros fatores. Cada fator, como a temperatura, a pressão osmótica, a tensão superficial, a radiação, o pH do solo, a quantidade e a qualidade dos nutrientes orgânicos disponíveis, apresentam, dependendo da espécie, um nível ótimo, que exercerá uma influência marcante no montante populacional dos organismos ou microrganismos (Lynch, 1986).

Graner \& Godoy Junior (1967) sugerem que o corte das leguminosas deve ser feito no início do florescimento, deixando-se as plantas cortadas no chão, para o início da decomposição da matéria orgânica. Dessa forma, o material verde serve como proteção ao solo contra a erosão, ação direta dos raios solares e contra o desenvolvimento das plantas daninhas.

A composição dos resíduos vegetais exerce forte influência na decomposição dos resíduos. A relação C:N, bem como o teor de lignina, governam boa parte dos processos de decomposição, mineralização e disponibilidade de $\mathrm{N}$ para as culturas em sucessão (Heinzmann, 1983).

A permanência da cobertura morta depende muito da velocidade de decomposição dos resíduos, isto é, quanto mais rápido os resíduos vegetais se decompõem, menor a proteção do solo. A decomposição está inversamente relacionada ao teor de lignina e à relação C:N (Costa et al., 1993). Assim, se o material em decomposição apresentar pouco $\mathrm{N}$ (alta relação C:N), este provavelmente será o fator 
limitante ao crescimento da população microbiana, que em média, apresenta C:N igual a 10.

Camargo \& Hermann (1928) estudaram a produção da parte aérea e das raízes de leguminosas e concluíram que as raízes do adubo verde dão resultados quase tão bons quanto aqueles em que se incorpora toda a planta. Segundo Neme (1959) raízes decompõem-se mais lentamente devido à sua composição, devendo o material orgânico incorporado ao solo conter, no mínimo, 1,5 \% de nitrogênio, pois, caso contrário, toda a amônia liberada no período de transformação será utilizada pelos microrganismos que atuam na sua decomposição.

Os adubos verdes devem ser incorporados ao solo, de preferência, após o florescimento e antes da frutificação, para garantir a adição de uma grande quantidade de material vegetal. A incorporação das plantas, após o desenvolvimento dos frutos, vai resultar no uso de um material mais pobre e possível infestação dos solos com as sementes do adubo verde (Costa, 1989).

Resíduos com uma relação C:N elevada (> 25) formam uma cobertura morta estável, a qual contribui para a estruturação do solo e proteção da superfície do impacto da chuva e radiação solar. Em resíduos com uma relação C:N baixa $(<25)$, a mineralização é mais rápida, mesmo sem a sua incorporação ao solo. Acredita-se que valores entre 23 e 24 para a relação $\mathrm{C}: \mathrm{N}$ favoreçam a mineralização uniforme do nitrogênio, com reflexos positivos sobre o suprimento desse nutriente às espécies não leguminosas em sucessão (Derpsh et al., 1985; Heinzmann, 1983; Teixeira, 1988).

O plantio dos adubos verdes de verão deverá ser feito no início das águas (outubro - novembro) para maior formação de massa vegetal. Ele pode ser realizado em linhas (espaçadas de 0,5 m em média) ou a lanço. A adubação verde no inverno é especialmente recomendada para solos muitos arenosos, erodidos e com baixa formação de cobertura verde natural. Atualmente, o nabo forrageiro tem sido o mais utilizado devido ao seu fácil manejo; por permitir o abrigo de inimigos naturais e também pelo seu sistema radicular pivotante, o qual contribui para a descompactação do solo. 


\subsubsection{Efeitos de adubos verdes sobre plantas daninhas}

Um adubo verde pode inibir a germinação ou o estabelecimento de plantas daninhas. Neme et al. (1959) verificaram num dos trabalhos pioneiros no Brasil os efeitos do feijão-de-porco na dinâmica de populações de plantas daninhas, observando a relativa ação desta planta como inibidor do desenvolvimento das plantas de tiririca, em área de cultivo de milho (Zea mays L.).

Teasdale \& Daughtry (1993) verificaram que uma vegetação viva intercepta luz vermelha $(660 \mathrm{~nm})$ em menor quantidade e a luz vermelha distante $(710 \mathrm{~nm})$ numa taxa suficiente, de tal forma que a luz difusa que atinge o solo abaixo da folhagem do adubo verde induz à dormência das sementes de plantas daninhas, pois o fitocromo é convertido para forma inativa.

Diversas pesquisas realizadas com adubos verdes têm mostrado uma redução nas populações de plantas daninhas em alguns sistemas de produção. Buckle (1992) verificou que várias leguminosas, depois de estabelecidas na cultura do milho, reduziram a biomassa de plantas daninhas, quando comparado com a testemunha sem a presença de cobertura. Jarillo (1994) testou diferentes coberturas vivas na cultura de laranja para o controle de plantas daninhas. Os resultados obtidos mostraram que a mucuna foi a melhor espécie para o controle das principais plantas daninhas.

Em Pato Branco, Estado de Paraná, uma pesquisa com leguminosas incluindo Cajanus cajan, intercaladas com a cultura do milho, resultou no bom controle das plantas daninhas, variando conforme a espécie intercalada (Skora, 1993). Severino (2000) avaliou o amendoim forrageiro (Arachis pintoi), a crotalária (C.juncea), e o feijão guandu-anão em áreas com infestação das plantas daninhas capim-colonião, capimbraquiária (Brachiaria decumbems Stapf) e picão-preto na cultura do abacate. Os

resultados obtidos mostraram que $C$. juncea foi o adubo verde que, de forma geral, apresentou maior eficiência na supressão das plantas daninhas em estudo. Rupeer (1987) constatou que $C$. ochroleuca possui um efeito supressor de plantas daninhas, especialmente no controle de capim-colchão e tiririca.

Em Sete Lagoas, MG, foi conduzido um estudo por Prates et al. (2000), no qual foi avaliado o efeito da parte aérea do adubo verde leucena, na cultura do milho, sobre o 
controle das plantas daninhas. Os resultados das avaliações indicaram redução nas populações de plantas daninhas, com o aumento do período de adição de leucena no solo. Fernandes et al. (1999) avaliaram em Lagarto, SE, a fitomassa de calopogônio, mucuna-preta, feijão-de-porco, guandu, e crotalária sob diferentes densidades de semeadura, bem como o crescimento das plantas daninhas, verificando que o feijão-deporco foi a leguminosa mais eficiente no controle de plantas daninhas, mesmo nas menores densidades de semeadura.

\subsubsection{Efeitos da cobertura morta na população de plantas daninhas}

Adegas (1997) diz que a cobertura morta deixada na superfície do solo funciona como um elemento isolante, reduzindo a amplitude térmica e hídrica no solo e filtrando os feixes de luz de ondas longas. O processo de germinação das plantas daninhas, estando intimamente ligados a esses fatores, reduz substancialmente devido à presença de grande quantidade de cobertura morta. Os efeitos da cobertura morta sobre as plantas daninhas devem ser analisados sob três aspectos: físico, biológico e químico.

O efeito físico da cobertura morta é bastante importante na regularização da germinação e na taxa de sobrevivência de algumas espécies. Em termos de efeitos sobre o processo germinativo, pode-se exemplificar como uma redução de germinação de sementes fotoblásticas positivas e de sementes que necessitam grande amplitude térmica para iniciar o processo. É amplamente conhecido como a cobertura morta reduz as oscilações diárias de variações térmicas e hídricas na região superficial do solo. O efeito físico da cobertura morta também reduz as oportunidades de sobrevivência de plantas daninhas com pequenas quantidades de reservas de sementes. Muitas vezes as reservas não são suficientes para garantir a sobrevivência de plântulas no espaço percorrido dentro da cobertura morta para ter acesso à luz e iniciar o processo fotossintético (Alves \& Pitelli, 2001).

No efeito biológico, a presença da cobertura morta vai criar condições para a instalação de uma densa e diversificada microbiocenose na camada superficial do solo. Na composição desta microbiocenose, há uma grande quantidade de organismos que podem utilizar sementes de plantas daninhas como fonte de energia, para sua 
multiplicação. De maneira geral, os microrganismos exercem importantes funções de deterioração e perda da viabilidade dos diversos tipos de propágulos no solo. Além disso, deve se considerar que a cobertura morta cria um ambiente seguro para alguns predadores de sementes e plântulas, como os roedores, insetos e outros pequenos animais (Alves \& Pitelli, 2001).

Existe uma relação alelopática entre a cobertura morta e as plantas daninhas presentes no banco de sementes no solo (Almeida, 1988). Depois da morte das plantas ou de seus órgãos, os aleloquímicos são inicialmente liberados pela lixiviação dos resíduos. Além disso, os microrganismos presentes no solo podem induzir à produção de compostos tóxicos por degradação enzimática dos conjugados, os polímeros presentes nos tecidos. Um exemplo deste processo é a ação de microrganismos em glicosídeos cianogênicos presentes em capim-massambará com uma produção de duas toxinas: ácido cianídrico (HCN) e benzaldeídos (Einhellig, 1986; Rizvi \& Rizvi, 1992). A atividade alelopática da cobertura morta dependerá diretamente da qualidade de material vegetal depositado na superfície do solo, do tipo de solo, da população microbiana, das condições climáticas e da composição específica das comunidades de plantas daninhas (Tousson, 1968; Grodzinsky, 1992).

Vários estudos têm sido conduzidos com o objetivo de determinar o manejo de cobertura morta no controle de plantas daninhas. No Brasil, foi demonstrada a eficácia da cobertura morta para várias espécies de cultivos de inverno, determinando-se, inclusive, uma relação de seletividade na interação cobertura morta e planta daninha.

Price (1997) menciona que a mucuna pode suprimir o crescimento de plantas daninhas como tiririca e sapé (Imperata brasiliensis Trin), devido à uma substância alelopática denominada L-Dopa. Este estudo demonstrou que a mucuna, além de evitar o crescimento das plantas daninhas por sombreamento, também tem um efeito alelopático que inibe o crescimento de plantas daninhas.

\subsubsection{Controle Químico}

É o tipo de controle no qual são usados produtos químicos que, em concentrações convenientes, têm a finalidade de inibir o desenvolvimento ou provocar a morte das 
plantas daninhas (Durigan, 1988). Os estudos da utilização de herbicidas para o controle de plantas daninhas em pomares de cítricos foram iniciados na década de 1950. A partir daí, houve uma evolução muito grande em sua utilização nas diversas regiões do mundo. No Brasil, houve um incremento na utilização do controle químico principalmente pela escassez de mão de obra e pela maior eficiência dos herbicidas em relação aos métodos tradicionais.

É preciso ter conhecimento em relação à cultura, às plantas daninhas e as características físicas e químicas dos produtos a serem utilizados, bem como do solo (Caetano, 1980). A escolha do produto e o modo de ação são de grande importância, uma vez que as injúrias produzidas nas plantas pelos produtos podem se refletir por longo período de tempo, com reflexos na produção dos citros, cujo custo de instalação é muito oneroso. O início do retorno do investimento realizado se dá a médio prazo e a sua viabilidade econômica depende da alta produtividade por um longo período.

\subsection{Manejo Integrado de plantas daninhas em citros}

Vários são os métodos de controle das plantas daninhas utilizados na cultura dos citros, com destaque para os métodos mecânicos (roçadeiras), culturais (cobertura verde ou morta) e químicos (herbicidas de aplicação em pós-emergência e pré-emergência).

Esses métodos têm sido bastante estudados, podendo ser encontrados na literatura vários trabalhos realizados com o objetivo de avaliar seus efeitos em aplicações realizadas na linha ou entrelinha da cultura, de forma isolada ou integrada.

São José (1988) avaliou o efeito do manejo de plantas daninhas pelo uso de capina manual, herbicida de aplicação em pós-emergência (paraquat), cobertura verde com lab-lab e mucuna-preta, herbicida de aplicação em pré-emergência (diuron) e gradagem na formação de um pomar de laranja 'Hamlin' enxertada sobre limão 'Cravo', localizado em Bebedouro, S.P. Nos tratamentos de cobertura verde e gradagem foram realizadas capinas manuais nas linhas de laranja. O melhor controle das plantas daninhas ocorreu no tratamento com diuron; os maiores diâmetros de tronco e produtividade ocorreram nos tratamentos com diuron e capina; e os maiores diâmetros de copa ocorreram nos tratamentos com diuron, gradagem e capina. Os tratamentos não 
influenciaram a altura das laranjeiras, teores de nutrientes foliares, matéria orgânica do solo e qualidade de frutos, até o quinto ano de formação do pomar. A infiltração de água no solo foi maior no tratamento com capina e menor com diuron.

Num pomar de 'Valência’ enxertada em limão ‘Cravo’, em Itápolis-SP, Tersi et al. (1999) avaliaram os efeitos da aplicação de herbicida (glyphosate) na linha e roçadeira na entrelinha, herbicida na linha e grade na entrelinha, herbicida na linha e na entrelinha, grade na linha e na entrelinha, roçadeira na linha e na entrelinha, rotativa na linha e grade na entrelinha e testemunha sem controle. Os efeitos na produção somente foram observados no quarto ano consecutivo de aplicação dos tratamentos. O crescimento da planta, não foi afetado pelos diferentes tratamentos. O teor foliar de nitrogênio foi reduzido na testemunha sem controle, sendo esse efeito atribuído à competição com as plantas daninhas. Para os demais macro e micronutrientes não foi constatado efeito significativo devido à interferência das plantas daninhas. Continuando esse estudo, Tersi (2001) avaliou as três safras subsequentes sendo constatado que os tratamentos sem mobilização do solo apresentaram produtividades iguais ou superiores aos demais tratamentos. Os resultados para a altura de plantas e teores foliares de macro e micronutrientes foram parecidos aos obtidos nos anos anteriores. A maioria dos índices tecnológicos não foi afetada nas três safras (peso dos frutos, peso do suco por fruto, rendimento de suco, brix, ratio, quilograma de sólidos solúveis por caixa). A matéria orgânica, a CTC e os teores de fósforo, potássio e cálcio do solo não foram afetados pelos tratamentos e ocorreram pequenas variações no $\mathrm{pH}$, teor de magnésio, soma de bases e saturação por bases. O tratamento com rotativa na linha reduziu o tamanho de agregados na superfície do solo e promoveu maior desestruturação superficial do solo, na projeção da copa, reduzindo a porosidade total.

O efeito de dois sistemas de manejo de plantas daninhas sobre algumas características físicas do solo, em cinco pomares cítricos da Bahia e Sergipe, foi avaliado por Carvalho et al. (2001). O primeiro manejo foi o utilizado pelo produtor, o qual constou de três capinas manuais nas linhas de plantio e três gradagens nas entrelinhas, enquanto que o sistema de manejo proposto como uma alternativa constou de duas aplicações de glyphosate nas linhas de plantio associado ao plantio de feijão-de-porco 
nas entrelinhas. Os resultados obtidos mostraram que o sistema proposto contribuiu para reduzir a densidade do solo e aumentar a porosidade total. A velocidade inicial de infiltração da água no solo, a infiltração acumulada e o armazenamento de água foram maiores no sistema proposto. Ainda avaliando esses sistemas de manejo de plantas daninhas, Carvalho et al. (2002) determinaram, em duas áreas na Bahia, que o sistema proposto apresentou melhores resultados para a produtividade da cultura.

Em um pomar de tangerina 'Ponkan’ sobre limão 'Cravo', Neves et al. (1998) testaram os seguintes manejos de entrelinha: plantio da leguminosa perene Indigofera campestris (Bong.); plantio da leguminosa perene Arachis prostata; plantio da leguminosa anual mucuna cinza (S. pruriens); gradagem no período seco com roçadeira no período de chuvas; e capina manual. Os resultados mostraram, após nove anos de condução do experimento, que a produtividade, a qualidade dos frutos (peso médio, rendimento em suco, brix, acidez e ratio) e a nutrição das plantas (macro e micronutrientes) não foram significativamente afetadas pelos manejos de entrelinha. Entre os atributos químicos do solo, apenas a matéria orgânica foi afetada, aumentando nos tratamentos com $A$. prostata e gradagem/roçadeira.

Victoria Filho (1983), no Estado de São Paulo, realizando experimentos com uso contínuo de herbicidas em pomares de laranja 'Pêra' e 'Natal', enxertadas sobre limão 'Cravo', com dois e quatro anos de idade, respectivamente, constatou que todos os herbicidas apresentaram controle de aceitável a excelente das plantas daninhas, dependendo da composição específica das plantas daninhas e aqueles que apresentaram melhores índices de controle e efeitos residuais mais prolongados foram: bromacil + diuron, diuron, bromacil, terbacil, ametrine + secbumetone, simazine e atrazine. Dos herbicidas de aplicação em pós-emergência os melhores índices de controle foram obtidos com glyphosate e paraquat. Não houve interferência na qualidade e produção de frutos, em função dos herbicidas utilizados.

Caetano et al. (2001) avaliaram as possíveis influências de diferentes sistemas de manejo de plantas daninhas na cultura dos citros sobre o "banco" de sementes de plantas daninhas. Na linha de plantio da laranja 'Pêra' enxertada sobre limão 'Cravo' foram aplicados os herbicidas diuron, em pré-emergência, ou glyphosate, em pós-emergência, 
associados a cinco práticas de manejo na entrelinha da cultura: gradagem, roçada, dose reduzida de glyphosate, guandu e lab-lab. O herbicida glyphosate permitiu a formação de maior população de sementes de plantas daninhas quando comparado com o diuron, na linha de citros. O plantio de leguminosas reduziu a população de sementes de plantas daninhas.

Atualmente, o manejo de diferentes tipos de vegetações (incluindo plantas daninhas) esta inserido como atividade de importância primária no processo de produção sustentável, caracterizado por um conjunto de ações com o objetivo de se obter a otimização nutricional das plantas e das condições ambientais do pomar.

Uma técnica que vem sendo desenvolvida e utilizada por alguns produtores como uma opção de manejo sustentável, baseia-se no manejo da vegetação com roçadeiras especialmente projetadas para cortar e lançar a sua massa sob a projeção da copa com o objetivo de formar uma cobertura morta sobre o solo. Essa prática, quando bem conduzida desde a implantação do pomar, pode a ajudar a diminuir a aplicação de herbicidas na linha do plantio.

Segundo Sanches (1998), existe uma série de gramíneas que poderiam ser utilizadas com esta finalidade; no entanto algumas delas apresentam inconvenientes. $\mathrm{O}$ capim-marmelada forma uma excelente biomassa mas apresenta autoalelopatia, pois a decomposição de sua matéria seca impede sua própria germinação. A braquiária-peluda (Braquiaria ruziziensis R. Germ \& Evrard) não provoca interferência à planta cítrica, não é alelopata e nem concorrente. No período seco, não concorre com água, pois seca antes do citros sofrer qualquer estresse hídrico. Floresce praticamente uma vez só, no outono, e só requer ser plantada uma única vez para se instalar definitivamente.

Segundo Cabrerá \& Yamada (2002), com o manejo do mato ocorre a formação de um tapete de matéria orgânica embaixo da saia do pomar. O mato desempenha papel de herbicida, pois à medida que é roçado e depositado em sucessivas camadas embaixo do pé de laranja forma-se uma cobertura morta praticamente não nasce mato, as sementes fotoblásticas positivas não germinam e as fotoblásticas negativas germinam, mas não conseguem romper a camada formada pelo tapete de mato roçado. 


\section{MATERIAIS E MÉTODOS}

$\mathrm{Na}$ presente pesquisa foram conduzidos dois experimentos em condições de campo e quatro em casa de vegetação na área experimental do departamento de Produção Vegetal da Escola Superior de Agricultura “Luiz de Queiroz”, da Universidade de São Paulo, localizada no município de Piracicaba-SP, no período compreendido entre novembro de 2002 e novembro do 2003.

O município de Piracicaba, Estado de São Paulo, apresenta as seguintes coordenadas geográficas: altitude de $560 \mathrm{~m}$, latitude $22^{\circ} 45^{\prime} 5^{\prime}$ ' e longitude de $47^{\circ} 38^{\prime}$ W. Segundo a classificação de Köeppen, o clima da região é do tipo Cwa, ou seja, tratase de clima mesotérmico, úmido tropical com inverno seco. O solo da área experimental de acordo com a classificação de solos, é Podzólico Vermelho-Amarelo-Distrófico, Tb, A moderado com textura média (Vidal \& Sparoveck, 1993). Os dados referentes às precipitações pluviométricas e temperaturas médias mensais durante a condução dos experimentos encontram-se na Tabela 1. Os dados foram obtidos junto à área de Física e Meteorologia, do Departamento de Ciências Exatas da ESALQ/USP.

\subsection{Experimento 1: Manejo mecânico de diferentes coberturas vegetais num pomar em produção}

A implantação do pomar foi realizada em novembro de 1995, com espaçamento de plantio 7m x 3m. A variedade plantada foi a Pêra (Citrus sinensis (L.) Osbeck) enxertada sobre limão cravo (Citrus limonia (L.) Osbeck). Análises de solo foram realizadas anteriormente à instalação dos experimentos, com o objetivo de determinar as 
quantidades de nutrientes disponíveis. Os resultados encontram-se na Tabela 2.

Tabela 1. Dados pluviométricos e temperaturas mensais (durante os meses de condução dos ensaios). Piracicaba, S.P. 2003 - USP/ESALQ

\begin{tabular}{lcccccc}
\hline ANO & Mês & $\begin{array}{c}\text { Precipitação } \\
(\mathbf{m m})\end{array}$ & $\begin{array}{c}\text { U.R } \\
\mathbf{\%}\end{array}$ & $\begin{array}{c}\text { T. máxima } \\
\left({ }^{\circ} \mathbf{C}\right)\end{array}$ & $\begin{array}{c}\text { T. mínima } \\
\left({ }^{\circ} \mathbf{C}\right)\end{array}$ & $\begin{array}{c}\text { T. média } \\
\left({ }^{\circ} \mathbf{C}\right)\end{array}$ \\
\hline 2002 & 10 & 48,9 & 69,7 & 33,0 & 18,5 & 25,0 \\
& 11 & 166,1 & 81,3 & 29,9 & 18,6 & 23,6 \\
& 12 & 169,1 & 85,7 & 30,7 & 19,8 & 24,3 \\
& 01 & 297,6 & 92,0 & 29,1 & 20,1 & 23,7 \\
& 02 & 52,5 & 85,0 & 31,9 & 20,4 & 25,3 \\
& 03 & 177,5 & 80,6 & 29,4 & 18,5 & 23,2 \\
& 04 & 55,0 & 76,5 & 28,4 & 16,5 & 21,8 \\
& 05 & 54,2 & 75,0 & 25,3 & 11,8 & 18,1 \\
& 06 & 8,9 & 74,0 & 27,5 & 12,4 & 19,2 \\
& 07 & 16,4 & 65,8 & 26,4 & 10,9 & 18,2 \\
& 08 & 17,6 & 65,9 & 25,8 & 10,6 & 17,7 \\
& 09 & 42,8 & 63,1 & 26,7 & 13,6 & 19,9 \\
& 10 & 88,6 & 66,4 & 29,6 & 16,2 & 22,3 \\
& 11 & 138,3 & 72,5 & 29,2 & 17,5 & 22,6 \\
12 & 133,1 & 97,0 & 30,2 & 19,3 & 24,0 \\
\hline
\end{tabular}

Tabela 2. Análise química do solo da área experimental. Piracicaba, S.P. 2002 USP/ESALQ

\begin{tabular}{ccccccccccccc}
\hline $\begin{array}{c}\mathrm{pH} \\
\mathrm{CaCl}^{2}\end{array}$ & $\begin{array}{c}\mathrm{M} . \mathrm{O} \\
\mathrm{g} / \mathrm{dm}^{3}\end{array}$ & $\begin{array}{c}\mathrm{P} \\
\mathrm{mg} / \mathrm{dm}^{3}\end{array}$ & $\mathrm{~S}$ & $\mathrm{~K}$ & $\mathrm{Ca}$ & $\begin{array}{c}\mathrm{Mg} \\
\mathrm{mmolc} / \mathrm{dm}^{3}\end{array}$ & $\mathrm{Al}$ & $\mathrm{H}+\mathrm{Al}$ & $\mathrm{SB}$ & $\mathrm{T}$ & $\begin{array}{c}\mathrm{V} \\
\mathrm{M}\end{array}$ & \\
\hline 4,4 & 15 & 5 & 2 & 0,1 & 22 & 6 & 6 & 31 & 28,1 & 59,1 & 48 & 18 \\
\hline
\end{tabular}


O solo foi preparado de maneira convencional, ou seja, nas entrelinhas foram realizadas uma roçagem, uma gradagem leve e um nivelamento do terreno. Em seguida, foi feita a semeadura dos diferentes adubos verdes: lab-lab, com um espaçamento de 0,5 m entre linhas, com 10 sementes por metro linear e o guandu-anão, com espaçamento de 0,5 m entre linhas e 20 sementes por metro linear. Para realizar estas operações fez-se uso de semeadora tratorizada. O plantio do milheto foi efetuado a lanço, depois de devida pesagem em balança de precisão, obtendo o valor de 200 gramas $/ 135 \mathrm{~m}^{2}$. Posteriormente, realizou-se a incorporação superficial das sementes com um rastelo. Devido à pouca precipitação apresentada durante o final do ano foi necessário realizar um replante do guandu-anão nos lugares onde existiam falhas.

Aos 90 dias após a semeadura dos diferentes adubos verdes foi feita uma adubação de acordo as recomendações, indicadas pelas análises químicas apresentadas na Tabela 2. O delineamento experimental utilizado foi de blocos casualizados no esquema fatorial 4 x 2 com três repetições. Os tratamentos utilizados se encontram na Tabela 3.

Tabela 3. Tratamentos utilizados no experimento com manejo mecânico de diferentes coberturas vegetais num pomar em produção Piracicaba, S.P. 2003 USP/ESALQ

\section{Tratamentos}

1.- Lab-lab - Adubação em área total

2.- Lab-lab - Adubação na projeção da copa da planta cítrica

3.- Guandu-anão - Adubação em área total

4.- Guandu-anão - Adubação na projeção da copa da planta cítrica

5.- Infestação natural - Adubação em área total

6.- Infestação natural - Adubação na projeção da copa da planta cítrica

7.- Milheto - Adubação em área total

8.- Milheto - Adubação na projeção da copa da planta cítrica 
A adubação em área total consistiu em aplicar os diferentes adubos sobre as vegetações utilizadas. A quantidade de adubos aplicados foram $250 \mathrm{~g}$ de uréia $+250 \mathrm{~g}$ de superfosfato triplo +40 g de ulexita, perfazendo um total de 540 g/planta ou 4860 g/parcela. Na adubação sobre a projeção da copa da planta citrica foram aplicados os mesmos adubos nas mesmas quantidades, variando apenas a forma de aplicação, a qual foi realizada de forma convencional, aplicando-se $540 \mathrm{~g} /$ planta. Cada parcela teve uma área $189 \mathrm{~m}^{2}$, apresentando nove plantas.

\subsubsection{Propriedades Químicas do solo.}

As amostras para análise química do solo foram retiradas na linha das plantas cítricas. Foram coletadas amostras simples a profundidades de 0-10 e 10-20 cm, em número de 6 por parcela. A seguir foram homogeneizadas, formando uma amostra composta. Posteriormente, foram encaminhadas para análise, junto ao Laboratório de Fertilidade do Solo da Escola Superior de Agricultura “Luiz de Queiroz”, USP.

Foram determinados os teores dos macronutrientes (fósforo, potássio, cálcio e magnésio), matéria orgânica, $\mathrm{pH}, \mathrm{H}^{+}+\mathrm{Al}^{++}$, $\mathrm{S}$ e saturação de bases (SB).

Os dados obtidos para cada um dos parâmetros avaliados, foram submetidos à análise de variância. As médias dos tratamentos foram confrontadas pelo teste de Tukey ao nível de 5\% de probabilidade.

\subsection{Experimento 2: Manejo mecânico de diferentes coberturas num pomar em formação}

A implantação do pomar foi realizada com espaçamento de plantio $4 \mathrm{~m}$ x $6 \mathrm{~m}$. A variedade plantada foi Pêra enxertada sobre tangerina Sunki (C. sunki Hort. ex Tan.). Nesta área foi realizada uma aplicação de calcário dolomítico, a $1 \mathrm{t} \mathrm{ha}^{-1}$, para elevação da saturação de bases, indicada pelas análises químicas de solo, que apresentava as características que encontram-se na Tabela 4. 
Tabela 4. Análise química do solo da área experimental. Piracicaba, S.P. 2002 USP/ESALQ

\begin{tabular}{ccccccccccccc}
\hline $\begin{array}{c}\mathrm{pH} \\
\mathrm{CaCl}^{2}\end{array}$ & $\begin{array}{c}\mathrm{M} . \mathrm{O} \\
\mathrm{g} / \mathrm{dm}^{3}\end{array}$ & $\begin{array}{c}\mathrm{P} \\
\mathrm{mg} / \mathrm{dm}^{3}\end{array}$ & $\mathrm{~S}$ & $\mathrm{~K}$ & $\mathrm{Ca}$ & $\begin{array}{c}\mathrm{Mg} \\
\mathrm{mmolc} / \mathrm{dm}^{3}\end{array}$ & $\mathrm{Al}$ & $\mathrm{H}+\mathrm{Al}$ & $\mathrm{SB}$ & $\mathrm{T}$ & $\mathrm{V}$ & $\mathrm{M}$ \\
& & & & & & & $\%$ & $\%$ \\
\hline 4,9 & 10 & 5 & 20 & 0,1 & 21 & 9 & 0 & 20 & 30,1 & 50,1 & 60 & 0 \\
\hline
\end{tabular}

O solo foi preparado de forma convencional, com uma roçagem, uma gradagem leve e um nivelamento de terreno. Em seguida foi feita a semeadura dos diferentes adubos verdes crotalária e guandu, cujas quantidades de sementes utilizadas foram de 25 e 16 sementes/m linear respectivamente, com espaçamento de 0,5 m entre linhas. Essa operação também foi realizada com semeadora tratorizada. O plantio do milheto foi feito a lanço, após a devida pesagem em balança de precisão, semeando 150 gramas/parcela, com posterior incorporação superficial das sementes com um rastelo.

Além das coberturas vegetais semeadas incluiu-se uma mistura de diferentes adubos verdes (lab-lab + guandu + crotalária), na relação de 3:1:1. A semeadura foi realizada a lanço. Uma última vegetação incluída nos tratamentos foi a infestação natural do pomar, a qual foi constituída principalmente por capim-colonião. Devido à pouca precipitação apresentada no final do ano, houve a necessidade de realizar um replante da crotalária e do guandu nos lugares onde existiam falhas. O delineamento experimental utilizado foi de blocos casualizados com quatro repetições. As unidades experimentais foram compostas por 6 plantas. A área de cada parcela foi de $144 \mathrm{~m}^{2}$.

Os tratamentos utilizados no experimento com manejo mecânico de diferentes coberturas num pomar em formação foram: 1. Crotalária, 2. Milheto, 3 Guandu, 4. Infestação natural e 5. Mistura de adubos verdes (lab-lab + guandu + crotalária) na relação 3:1:1.

Antes da realização da roçagem das diferentes vegetações, foi feita uma capina com enxada, eliminando-se todas as plantas daninhas surgidas sobre a linha das plantas cítricas nos dois experimentos. O manejo mecânico das diferentes vegetações foi realizado mediante a utilização de roçadeira lateral, marca KAMAQ, modelo NINJA 
MAC 260, desenhada para projetar o material verde cortado, sobre a projeção da copa da árvore cítrica, formando dessa maneira uma camada de cobertura morta.

A partir da roçagem das coberturas vegetais, foram realizadas contagens de plantas daninhas nos respectivos tratamentos aos 30, 60 e 90 dias. As contagens foram realizadas mediante utilização de um quadrado metálico com dimensões de 0,5 x 1,0m, lançado 6 vezes no primeiro experimento e 4 no segundo. Os dados foram submetidos à análise de variância, sendo que as interações significativas tiveram suas médias comparadas entre si através do teste de Tukey, ao nível de 5\% de probabilidade.

\subsection{Experimentos em casa de vegetação}

Os experimentos para verificar o efeito de coberturas mortas no controle das plantas daninhas foram instalados no mês de abril de 2003. O solo foi coletado na profundidade de $0-20 \mathrm{~cm}$ da área experimental do departamento de Produção Vegetal, local onde estavam sendo realizados os experimentos de campo, posteriormente foi peneirado, utilizando-se peneira com malha de $0,20 \mathrm{~mm}$, e utilizado para preenchimento dos vasos com $200 \mathrm{~cm}^{3}$ de solo/vaso.

Nesses experimentos, foram semeadas onze espécies de plantas daninhas. No experimento 1, foram utilizadas sete espécies que apresentaram em levantamento realizado anteriormente, alta freqüência de ocorrência no pomar em produção. No experimento 2, foram utilizadas as quatro espécies restantes, que apresentaram também alta freqüência de ocorrência no pomar em formação.

No experimento 1, foram utilizadas as seguintes espécies de plantas daninhas: poaia, erva-palha, falsa-serralha, picão-preto, corda-de-viola, capim-colchão e capimcolonião. Foram utilizados os resíduos das espécies vegetais: lab-lab, guandu-anão, milheto e capim-colonião para verificar o efeito nas plantas daninhas em condições de pós-emergência.

No experimento 2, foram utilizadas as seguintes plantas daninhas: poaia, picãopreto, guanxuma, tiririca e os resíduos das espécies vegetais: crotalária, guandu, milheto, capim-colonião, e uma mistura de três adubos verdes, composta por lab-lab + crotalária 
+ guandu, na relação 3:1:1 para verificar o efeito nas plantas daninhas em condições de pós-emergência.

As quantidades de sementes de plantas daninhas utilizadas na semeadura em ambos os ensaios foram determinadas de acordo com o teste de germinação para cada espécie. Os primeiros experimentos (1 e 2) foram montados no dia 7 de abril de 2003 e aos quinze dias após o plantio das plantas daninhas foi realizado um raleio, de tal forma que ficassem 10 plantas daninhas/vaso. No dia 22 de abril foram instalados outros dois experimentos (3 e 4) com a mesma quantidade de vasos e espécies de plantas daninhas dos experimentos 1 e 2, com o objetivo que, ao final os ensaios, possuíssem o mesmo número de repetições e as mesmas espécies de plantas daninhas, para verificar o efeito nas plantas daninhas em condições de pré-emergência.

Na etapa seguinte, efetuou-se a coleta das diversas vegetações que já estavam plantadas e que, nesse momento, apresentavam-se no estádio fenológico de início de florescimento. Todas as vegetações utilizadas foram cuidadosamente cortadas (apenas a parte aérea), colocadas em sacos devidamente identificados e levadas ao laboratório, onde foram trituradas de forma a se obter materiais homogêneos de consistência fina.

A quantidade de fitomassa para cada cobertura a ser colocada nos vasos foi baseada na quantidade que a roçadeira lateral havia depositado na linha das plantas cítricas nos experimentos de campo. Para isso, foi feito um levantamento das diferentes coberturas utilizadas, com um quadro metálico com dimensões de $0,5 \mathrm{~m} \times 1,0 \mathrm{~m}$. A quantidade de biomassa verde extraída foi pesada com objetivo de estabelecer a correlação das quantidades de fitomassa depositada pela roçadeira na unidade experimental de campo com a área do vaso.

Baseando-se nos dados da biomassa no campo, foi feito um corte fino de cada uma delas, as quais foram colocadas na superfície dos vasos nas quantidades de $30 \mathrm{~g}$ para o lab-lab e 45 g para as coberturas restantes, tendo uma testemunha para cada espécie de planta daninha que não recebeu vegetação. Os vasos foram submetidos ao sistema de irrigação diária, composto por microaspersores, controlados por um "timer", irrigando aproximadamente $5 \mathrm{~mm}$ cada vez que era acionado. A casa de vegetação possui um sistema automático de controle de temperatura e umidade relativa. 
As avaliações foram realizadas aos 30 dias após terem sido depositadas as vegetações na superfície dos vasos. As variáveis analisadas foram contagem do número de plantas daninhas por vaso e biomassa seca da parte aérea das plantas daninhas. O delineamento experimental foi de blocos casualizados no esquema fatorial 7 x 5 para os experimentos 1 e 3 e 4 x 6 para os experimentos 2 e 4 . Os tratamentos dos ensaios estão apresentados nas tabelas 5 e 6.

Tabela 5. Descrição dos fatores utilizados no delineamento fatorial 7 x 5 . Experimentos 1 e 3 na casa de vegetação com a utilização de coberturas vegetais para verificar o efeito nas plantas daninhas em condições de pós e pré-emergência. Piracicaba, S.P. 2003, USP/ESALQ

\section{Fatores}

\section{Descrição}

Coberturas vegetais (5)

Plantas daninhas (7)

\section{Lab-lab}

Guandu-anão

Vegetação Natural

Milheto

Ausência de Vegetação (Testemunha) 
Tabela 6. Descrição dos fatores utilizados no delineamento fatorial 4 x 6. Experimentos 1 e 3 na casa de vegetação com a utilização de coberturas vegetais para verificar o efeito nas plantas daninhas em condições de pós e pré-emergência. Piracicaba S.P. 2003, USP/ ESALQ

\begin{tabular}{cc}
\hline Fatores & Descrição \\
\hline Coberturas Vegetais (6) & Crotalária \\
Milheto & Guandu \\
Vegetação natural (Testemunha) & Mistura de adubos verdes \\
Ausência de Vegetação & \\
Plantas Daninhas (4) & Poaia \\
& Picão-preto \\
& Guanxuma \\
& Tiririca \\
\hline
\end{tabular}




\section{RESULTADOS E DISCUSSÕES}

\subsection{Experimento 1: Manejo mecânico de diferentes coberturas vegetais num pomar em produção}

Na tabela 7 estão apresentadas às médias da densidade do total de plantas daninhas presentes nas linhas das plantas cítricas de acordo com o tipo de vegetação que foi utilizada na entre-linha. A interação entre os fatores vegetação e adubação não foi significativa.

Tabela 7. Médias da densidade de plantas daninhas (plantas $/ \mathrm{m}^{2}$ ) - Determinações realizadas aos 30, 60, 90, 180 e 210 dias após a roçagem das diversas coberturas. Piracicaba, S.P. 2003 - USP/ESALQ

\begin{tabular}{lccccc}
\hline \multicolumn{1}{c}{ Coberturas $^{1}$} & \multicolumn{5}{c}{ Densidade de plantas daninhas } \\
& \multicolumn{5}{c}{ Dias após o corte } \\
& 10 & 60 & 90 & 180 & 210 \\
\hline Lab-lab & $10,83 \mathrm{~b}$ & $17,00 \mathrm{a}$ & $5,16 \mathrm{ab}$ & $17,33 \mathrm{a}$ & $20,00 \mathrm{~b}$ \\
Guandu-anão & $19,50 \mathrm{ab}$ & $16,00 \mathrm{a}$ & $6,33 \mathrm{ab}$ & $21,33 \mathrm{a}$ & $47,16 \mathrm{a}$ \\
Vegetação natural & $9,66 \mathrm{~b}$ & $9,66 \mathrm{a}$ & $3,33 \mathrm{a}$ & $7,833 \mathrm{a}$ & $13,33 \mathrm{~b}$ \\
Milheto & $24,66 \mathrm{a}$ & $19,66 \mathrm{a}$ & $10,00 \mathrm{~b}$ & $16,66 \mathrm{a}$ & $20,00 \mathrm{~b}$ \\
& & & & & \\
D.M.S. & 12.28 & 12.42 & 5,84 & 17,62 & 25,6 \\
\hline 1 & & & & & \\
\hline
\end{tabular}

${ }^{1}$ Médias seguidas por letras distintas diferem entre si a 5\% de significância pelo teste de Tukey.

Verifica-se pela Tabela 7 que, aos 30 dias após a roçagem o melhor controle de plantas daninhas de forma geral, foi obtido com vegetação natural com predominância 
de capim-colonião, e com o lab-lab. Na terceira época, aos 90 dias, o número de plantas daninhas $/ \mathrm{m}^{2}$ diminuiu consideravelmente em todos os tratamentos, provavelmente porque nessa época o fluxo de emergência diminui pela queda da temperatura e da umidade disponível no solo. A partir da quarta avaliação com o início das chuvas, o número de infestantes aumentou. Aos 210 dias após ter sido feito a roçagem, nota-se que o pior tratamento no controle de plantas daninhas foi o guandu-anão.

Na Tabela 8 encontram-se os dados de produção de fitomassa verde $/ \mathrm{m}^{2}$ depositada nas linhas cítricas após o corte com a roçadeira lateral. Verifica-se que o guandu-anão produziu uma grande quantidade de fitomassa, que se deve ao habito de crescimento da planta, que é arbustivo. (Silva, et al 1999).

Tabela 8. Quantidade de fitomassa verde $\left(\mathrm{g} / \mathrm{m}^{2}\right)$ depositada pela roçadeira lateral na linha da cultura. Piracicaba, S.P. 2003 - USP/ESALQ

\begin{tabular}{lc}
\hline \multicolumn{1}{c}{ Espécies de coberturas } & Quantidade de fitomassa \\
\hline Lab-lab & 2600 \\
Guandu-anão & 4020 \\
Vegetação Natural & 4000 \\
Milheto & 3500 \\
\hline
\end{tabular}

O comportamento similar, apresentado pelo lab-lab, guandu-anão, e a vegetação natural na densidade de plantas daninhas, pode ser atribuído a fenômenos físicos e alelopaticos. O fenômeno físico evita a entrada de luz e as oscilações térmicas que influenciam a germinação de diseminulos das plantas daninhas como tem sido relatado por Adegas (1997) e Pitelli (1985).

Outro aspecto a ser levado em consideração é a decomposição do material vegetal adicionado ao solo, que inicia quase imediatamente após a incorporação do material ao solo, devido à relação C:N. A velocidade de decomposição vai diminuindo a medida que a relação C:N vai se estreitando, tendendo para valores entre 10 e 12, que é a relação normal da matéria orgânica nos solos (Mello, 1988). Além disso a decomposição esta sujeita à interferência de inúmeros fatores. Segundo Lynch, (1986) fatores como a 
temperatura, a pressão osmótica, a tensão superficial, a viscosidade, a radiação, o pH do solo, podem exercer uma influência marcante na quantidade de microrganismos os quais podem acelerar a velocidade de decomposição das coberturas.

É importante observar que as espécies de plantas daninhas picão-preto, capimcolonião, capim-braquiária e guanxuma apareceram nas quatro espécies de cobertura utilizada nesta pesquisa (Tabela 9).

Tabela 9. Espécies predominantes de plantas daninhas encontradas nas diferentes coberturas aos 210 dias após da aplicação dos tratamentos. Valores médios de três repetições. Piracicaba, S.P. 2003 - USP/ESALQ

\begin{tabular}{lcccc}
\hline Cobertura morta & & \multicolumn{2}{c}{ Espécies de plantas daninhas/m } & \\
& Picão-preto & Capim colonião & Guanxuma & Capim-braquiaria \\
\hline Lab-lab & 4,5 & 4,0 & 3,0 & 2,0 \\
Guandu-anão & 6,6 & 4,1 & 8,8 & 3,6 \\
Vegetação natural & 2,6 & 1,8 & 1,3 & 1,0 \\
Milheto & 4,3 & 4,0 & 2,1 & 2,3 \\
\hline
\end{tabular}

Na Tabela 10 são apresentados os dados da densidade de plantas daninhas $/ \mathrm{m}^{2}$ na linha de citros em função do tipo de adubação executada. Observa-se que nas duas primeiras determinações realizadas aos 30 e 60 dias ocorreram, diferenças estatísticas, sendo que a adubação na projeção da copa apresentou maiores densidades de plantas daninhas que a adubação em área total, independentemente da cobertura utilizada. Estes resultados demonstram as hipóteses de Yamada (2000), que menciona que após o terceiro ano de plantio dos citros, a adubação poderia ser feita em área total que proporcionaria um aumento na produção de matéria seca das plantas utilizadas como cobertura propiciando um melhor efeito no controle da comunidade infestante. 
Tabela 10. Médias de densidade de plantas daninhas (plantas $/ \mathrm{m}^{2}$ ) - Determinações realizadas aos 30, 60, 90, 180 e 210 dias após a roçagem das diversas coberturas. Piracicaba, S.P. 2003 - USP/ESALQ

\begin{tabular}{lccccc}
\hline \multicolumn{1}{c}{ Tipo de adubação $^{1}$} & \multicolumn{5}{c}{ Densidade de plantas daninhas/m ${ }^{2}$} \\
& 30 & 60 & 90 & 180 & 210 \\
\hline Adubação em área total & $12,75 \mathrm{~b}$ & $11.50 \mathrm{~b}$ & $5,66 \mathrm{a}$ & $13.58 \mathrm{a}$ & $25.33 \mathrm{a}$ \\
Adubação na projeção da copa & $19,33 \mathrm{a}$ & $19.66 \mathrm{a}$ & $6.75 \mathrm{a}$ & $13.00 \mathrm{a}$ & $24.91 \mathrm{a}$ \\
& & & & & \\
D. M. S & 6,41 & 6,48 & 3,04 & 9,19 & 13,36 \\
\hline
\end{tabular}

${ }^{1}$ Médias seguidas por letras distintas diferem entre si a 5\% de Significância pelo teste de Tukey.

Na Tabela 11 são apresentados os dados médios de porcentagem de área coberta pelas plantas daninhas nas linhas cítricas em função do tipo de cobertura utilizada na entre-linha. Os dados permitem afirmar que a vegetação natural apresentou uma menor área coberta de plantas daninhas. Isto pode ser atribuído aos efeitos físicos e possíveis aleloquímicos liberados durante a decomposição dos resíduos da vegetação natural que limitam a infestação do mato.

Tabela 11. Porcentagem de área coberta de plantas daninhas nas diferentes coberturas aos 210 dias. Piracicaba, S.P. 2003 - USP/ESALQ

\begin{tabular}{cc}
\hline Coberturas $^{1}$ & Porcentagem de área coberta de daninhas \\
\hline Lab-lab & $24,50 \mathrm{a}$ \\
Guandu-anão & $19,00 \mathrm{ab}$ \\
Vegetação natural & $7,51 \mathrm{~b}$ \\
Milheto & $19,56 \mathrm{ab}$ \\
& \\
D.M.S & 13,18 \\
\hline
\end{tabular}

${ }^{1}$ Médias seguidas por letras distintas diferem entre si a 5\% de Significância pelo teste de Tukey. 
Na Tabela 12 estão apresentados os dados médios da matéria orgânica (\%), fósforo, potássio, cálcio e magnésio em função do tipo da adubação executada.

Tabela 12. Valores médios de determinações químicas do solo em duas profundidades (0-10 e 10-20 cm) num pomar em produção. Piracicaba, S.P. 2003 USP/ESALQ

\begin{tabular}{|c|c|c|c|c|c|c|c|c|c|}
\hline \multirow[t]{2}{*}{ Adubações $^{1}$} & \multicolumn{2}{|c|}{$\begin{array}{l}\text { Matéria orgânica } \\
\mathrm{mg} \mathrm{dm}^{-3}\end{array}$} & \multicolumn{2}{|c|}{$\begin{array}{l}\text { Fósforo } \\
\mathrm{mg} \mathrm{dm}^{-3}\end{array}$} & \multicolumn{2}{|c|}{ Potássio } & \multicolumn{2}{|c|}{$\begin{array}{l}\text { Cálcio } \\
\text { mmolc } \mathrm{dm}^{-3}\end{array}$} & Magnésio \\
\hline & \multicolumn{6}{|c|}{ Profundidade de amostragem $(\mathrm{cm})$} & & & \\
\hline & $0-10$ & $10-20$ & $0-10$ & $10-20$ & $0-10$ & $10-20$ & $0-10$ & $0-10$ & $10-20$ \\
\hline $\begin{array}{l}\text { Adubação em área } \\
\text { total }\end{array}$ & $20,7 \mathrm{a}$ & $17,7 \mathrm{a}$ & $25,5 \mathrm{a}$ & $7,8 \mathrm{a}$ & $2,2 \mathrm{a}$ & $2,1 \mathrm{a}$ & 19,7 a & $4,6 \mathrm{a}$ & $4,3 \mathrm{a}$ \\
\hline $\begin{array}{l}\text { Adubação na } \\
\text { projeção da copa. }\end{array}$ & $20,6 \mathrm{a}$ & $16,2 \mathrm{~b}$ & $25,8 \mathrm{a}$ & $7,2 \mathrm{a}$ & $1,7 \mathrm{~b}$ & $1,4 \mathrm{~b}$ & $20,7 \mathrm{a}$ & $4,1 \mathrm{a}$ & $3,2 \mathrm{a}$ \\
\hline D. M. S. & 1,2 & 1,1 & 8,5 & 3,3 & 0,2 & 0,5 & 3,5 & 0,9 & 2,1 \\
\hline
\end{tabular}

${ }^{1}$ Médias seguidas por letras distintas diferem entre si a 5\% de Significância pelo teste de Tukey.

Analisando a Tabela 12, verifica-se que o teor de matéria orgânica foi superior na camada superficial $(0-10 \mathrm{~cm})$, sem apresentar diferenças significativas entre os dois tipos de adubações realizadas. Na profundidade de $10-20 \mathrm{~cm}$, houve redução nos porcentuais, no entanto a adubação em área total apresentou um maior teor de matéria em relação à adubação na projeção da copa, havendo diferença significativa entre as duas formas de adubação. Concordando com resultados obtidos por Yamada (2000), o qual relata que quando se realiza adubação em área total, ocorrerá um incremento da cobertura vegetal e conseqüentemente um aumento na produção de matéria orgânica.

O fósforo apresentou valores maiores, na camada superficial $(0-10 \mathrm{~cm})$, contudo os dois tipos de adubações não apresentaram diferenças significativas.

Os teores de potássio foram maiores na adubação em área total, apresentando diferenças significativas entre as duas formas de adubação. No entanto na camada de 0$10 \mathrm{~cm}$, foi possível observar maiores teores desse nutriente. Provavelmente esse fato este relacionado com a maior eficiência na reciclagem de nutrientes, já que com a 
mineralização dos resíduos vegetais, os cátions são liberados na solução do solo nas formas inorgânicas, podendo ser absorvidos novamente pelas raízes ou adsorvidos às cargas negativas do solo dependentes de $\mathrm{pH}$. A menor lixiviação de $\mathrm{NO}_{3}^{-}$com íons acompanhantes, causa maior acúmulo de K na camada superior do solo (Cabrera, 2000).

Com relação ao magnésio, constatou-se que não houve diferenças nos teores encontrados nas duas formas de adubação.

Para o cálcio se observa que na profundidade de 0-10 cm, não houve diferenças entre os dois tipos de adubação, no entanto a adubação na projeção da copa apresentou uma maior concentração desse nutriente.

Na Tabela 13 estão apresentados os valores médios de concentração de cálcio na profundidade 10 -20 cm, em função das coberturas utilizadas e das adubações realizadas.

Tabela 13. Valores médios para cálcio na profundidade de 10-20 cm num pomar em produção. Piracicaba, S.P. 2003 - USP/ESALQ

\begin{tabular}{ccc}
\hline Coberturas $^{1}$ & Adubação em área total & Adubação na projeção da copa \\
\hline Lab-lab & $21,3 \mathrm{aA}$ & $10,1 \mathrm{bA}$ \\
Guandu anão & $9,3 \mathrm{aB}$ & $15,6 \mathrm{aA}$ \\
Vegetação Natural & $10,8 \mathrm{aB}$ & $13,0 \mathrm{aA}$ \\
MIlheto & $10,0 \mathrm{aB}$ & $10,0 \mathrm{aA}$ \\
& & \\
D. M. S & 1,8 (Colunas) & 7,6 (Linhas) \\
\hline
\end{tabular}

${ }^{1}$ Médias seguidas por letras distintas minúsculas na linha e maiúsculas na coluna diferem entre si a 5\% de significância pelo teste de Tukey.

Analisando-se a Tabela 13 em colunas, observou-se que nas parcelas onde foi realizada a adubação em área total a cobertura do lab-lab apresentou as maiores concentrações de cálcio, havendo diferenças significativas em relação às demais coberturas. Em relação à adubação na projeção da copa, o guandu apresentou os maiores teores desse nutriente, no entanto não houve diferença significativa em relação às demais coberturas.

Analisando as linhas, pode se observar que o lab-lab mostrou maior concentração quando foi realizada a adubação em área total, enquanto que para as demais coberturas 
os maiores teores foram encontrados nas parcelas onde foi realizada a adubação na projeção da copa.

\subsection{Experimento 2: Manejo mecânico de diferentes coberturas vegetais num pomar em formação}

Na Tabela 14 são apresentadas as médias da densidade do total de plantas daninhas presentes nas linhas das plantas cítricas de acordo com o tipo de vegetação que foi utilizado na entre-linha.

Tabela 14. Médias da densidade de plantas daninhas (plantas $/ \mathrm{m}^{2}$ ) - Determinações realizadas aos 30, 60, 90, 180 e 210 dias após a roçagem das diversas coberturas. Piracicaba, S.P. 2003 - USP/ESALQ

\begin{tabular}{lccccc}
\hline \multicolumn{1}{c}{ Coberturas $^{1}$} & \multicolumn{5}{c}{ Densidade de plantas daninhas } \\
& 30 & 60 & 90 & 180 & 210 \\
\hline Crotalária & $89,00 \mathrm{ab}$ & $88,00 \mathrm{a}$ & $18,00 \mathrm{a}$ & $14,75 \mathrm{a}$ & $106,50 \mathrm{a}$ \\
Milheto & $133,00 \mathrm{a}$ & $99,75 \mathrm{a}$ & $40,25 \mathrm{a}$ & $20,75 \mathrm{a}$ & $96,00 \mathrm{a}$ \\
Guandu & $125,25 \mathrm{a}$ & $109,75 \mathrm{a}$ & $29,50 \mathrm{a}$ & $17,75 \mathrm{a}$ & $118,75 \mathrm{a}$ \\
Vegetação natural & $72,75 \mathrm{~b}$ & $71,00 \mathrm{a}$ & $21,75 \mathrm{a}$ & $15,75 \mathrm{a}$ & $74,50 \mathrm{a}$ \\
Misturas de adubos verdes o corte & $76,00 \mathrm{~b}$ & $63,75 \mathrm{a}$ & $21,50 \mathrm{a}$ & $15,50 \mathrm{a}$ & $74,25 \mathrm{a}$ \\
& & & & & \\
D.M.S. & 45,29 & 81,98 & 39,40 & 14,49 & 113,1 \\
\hline
\end{tabular}

${ }^{1}$ Médias seguidas por letras distintas diferem entre si a 5\% de Significância pelo teste de Tukey.

De acordo com os dados apresentados na Tabela 14, aos 30 dias as menores densidades de plantas daninhas foram obtidas com a cobertura morta da vegetação natural e da mistura de adubos verdes (lab-lab + guandu + crotalária), as quais diferiram das coberturas mortas de milheto e guandu. Isto pode ser devido a que as misturas de adubos verdes produziram mais fitomassa que guandu e milheto, bem como um possível efeito causado pelos aleloquímicos liberados durante a degradação da fitomassa da 
vegetação natural (Tabela 15). Entre 60 e 210 dias não houve diferenças estatísticas entre as coberturas, pela degradação rápida da fitomassa bem como da agressividade das espécies presentes como tiririca, picão-preto, guanxuma e poaia.

Na Tabela 15 estão apresentados os dados da produção de fitomassa verde das coberturas utilizadas.

Tabela 15. Quantidade de fitomassa verde $\left(\mathrm{g} / \mathrm{m}^{2}\right)$ depositada pela roçadeira lateral na linha da cultura. Piracicaba, S.P. 2003 - USP/ESALQ

\begin{tabular}{cc}
\hline Espécies de coberturas & Quantidade de fitomassa \\
\hline Crotalária & 4380 \\
Milheto & 4080 \\
Guandu & 2280 \\
Vegetação natural & 2080 \\
Mistura de adubos verdes & 8500 \\
\hline
\end{tabular}

Na Tabela 16 são apresentados os dados médios de porcentagem de área coberta pelas plantas daninhas nas linhas cítricas em função do tipo de cobertura utilizada na entre-linha.

Tabela 16. Porcentagem de área coberta por plantas daninhas nas diferentes coberturas mortas aos 210 dias. Piracicaba, S.P. 2003 - USP/ESALQ

\begin{tabular}{cc}
\hline Coberturas $^{1}$ & Porcentagem de área coberta de daninhas \\
\hline Crotalária & $46,37 \mathrm{a}$ \\
Milheto & $50,87 \mathrm{a}$ \\
Guandu & $52,25 \mathrm{a}$ \\
Vegetação natural & $27,87 \mathrm{~b}$ \\
Mistura de adubos verdes & $43,62 \mathrm{ab}$ \\
& \\
D. M. S & 17.8
\end{tabular}

\footnotetext{
${ }^{1}$ Médias seguidas por letras distintas diferem entre si a 5\% de Significância pelo teste de Tukey.
} 
A menor porcentagem de cobertura de plantas daninhas foi obtida com a vegetação natural, que apresentou diferença significativa com as coberturas de crotalária, milheto e guandu. Os resultados são similares aos obtidos na área coberta de plantas daninhas no experimento 1, embora os dados de porcentagem de infestação neste experimento foram maiores.

\subsection{Experimentos em casa de vegetação}

Na tabela 17 estão apresentadas as médias de densidade de plantas daninhas/vaso aos 30 dias após a aplicação das coberturas vegetais sobre as plantas daninhas em condições de pós-emergência (Experimento 1).

Tabela 17. Médias de densidade de plantas daninhas (plantas/vaso) na avaliação realizada aos 30 dias após a instalação do experimento. Experimento 1 em casa de vegetação. Piracicaba, S.P. 2003 - USP/ESALQ

\begin{tabular}{|c|c|c|c|c|c|}
\hline \multirow[b]{2}{*}{$\begin{array}{l}\text { Plantas }^{1} \\
\text { daninhas }\end{array}$} & \multicolumn{5}{|c|}{ Coberturas vegetais } \\
\hline & Lab-lab & Guandu-anão & $\begin{array}{c}\text { Vegetação } \\
\text { natural }\end{array}$ & Milheto & Testemunha \\
\hline Poaia & $2,44 a^{2} \mathrm{C}$ & $0,71 \mathrm{bC}$ & $0,71 \mathrm{bC}$ & $1,00 \mathrm{bC}$ & $3,24 \mathrm{a}$ \\
\hline Capim colonião & $2,52 \mathrm{aC}$ & $2,48 \mathrm{aB}$ & $1,17 \mathrm{bC}$ & $2,46 \mathrm{aB}$ & 3,24 a \\
\hline Erva-palha & $1,95 \mathrm{bC}$ & $2,45 \mathrm{aB}$ & $1,56 \mathrm{bBC}$ & $2,47 \mathrm{aB}$ & $3,24 \mathrm{a}$ \\
\hline Falsa-serralha & 3,85 aA & 2,93 аAB & $2,48 \mathrm{aAB}$ & 2,68 aAB & 3,24 a \\
\hline Capim-colchão & $2,86 \mathrm{aBC}$ & $2,47 \mathrm{aB}$ & $1,00 \mathrm{cC}$ & 2,49 aAB & 3,24 a \\
\hline Corda-de-viola & $3,38 \mathrm{aAB}$ & 3,43 aA & $2,97 \mathrm{aA}$ & $3,40 \mathrm{aA}$ & $3,24 \mathrm{a}$ \\
\hline Picão preto & $2,74 \mathrm{aBC}$ & 2,51 aAB & $2,46 \mathrm{aAB}$ & $2,49 \mathrm{aAB}$ & $3,24 \mathrm{a}$ \\
\hline D. M. S. & & 0,92 (Colunas) & & (Linhas) & \\
\hline
\end{tabular}

${ }^{1}$ Para análise estatística os dados foram transformados segundo $\sqrt{x+0,5}$

${ }^{2}$ Médias seguidas por letras distintas minúsculas na linha e maiúsculas na coluna diferem entre si a 5\% de significância pelo teste de Tukey. 
Analisando-se, em colunas, a Tabela 17, verifica-se que, o lab-lab apresentou um maior efeito supressivo sobre a erva palha. O guandu-anão teve maior eficiência no controle da poaia e foi menos eficaz no controle da corda-de-viola. A vegetação natural foi mais eficaz no controle da poaia, capim-colchão e capim-colonião. O milheto teve um melhor controle sobre a poaia.

Ainda na mesma tabela, agora sendo analisadas nas linhas, pode-se notar que, para a planta daninha poaia, as coberturas da vegetação natural, guandu-anão e milheto, tiveram os melhores efeitos supressivos, reduzindo a infestação em 71\% para as duas primeiras e $69 \%$ para a terceira cobertura.

Em relação à planta daninha capim-colonião, observa-se que a cobertura da vegetação natural suprimiu com eficiência esta planta. Quando comparada com a testemunha, observa-se que esta cobertura reduziu a infestação em 63,9\%.

Para a erva-palha, a vegetação natural e o lab-lab, mostraram os melhores efeitos supressivos. Em relação à falsa-serralha nenhuma cobertura teve um efeito supressivo sobre esta planta.

Para à planta daninha capim-colchão pode-se observar que a cobertura da vegetação natural apresentou um melhor controle na densidade desta planta daninha quando comparada com a testemunha, com um efeito supressivo de 69,1\%.

Para a corda-de-viola e picão preto nenhuma cobertura mostrou um efeito supressivo.

Na Tabela 18, estão apresentadas as médias de produção de biomassa seca de plantas daninhas/vaso aos 30 dias após a aplicação das coberturas vegetais sobre as plantas daninhas em condições de pós-emergência (Experimento 1).

Analisando-se a Tabela 18 pode-se perceber que o milheto e a vegetação natural interferiram na produção da biomassa seca das plantas daninhas quando comparadas com a testemunha. Dentre as plantas daninhas, a que apresentou uma menor produção de biomassa seca independentemente da cobertura vegetal foi poaia (Tabela 19).

Na Tabela 19, estão apresentados os dados médios, da produção de biomassa seca de plantas daninhas/vaso aos 30 dias após a aplicação das coberturas vegetais em condições de pós-emergência (Experimento1). 
Tabela 18. Médias de produção de biomassa seca de plantas daninhas (g/vaso) em função da cobertura na avaliação realizada aos 30 dias após a instalação do experimento. Experimento 1 em casa de vegetação. Piracicaba, S.P. 2003 USP/ESALQ

\begin{tabular}{cc}
\hline Coberturas & Médias $^{1}$ \\
\hline Lab-lab & $1,24 \mathrm{a}$ \\
Guandu-anão & $1,09 \mathrm{ab}$ \\
Milheto & $0,94 \mathrm{~b}$ \\
Vegetação natural & $1,02 \mathrm{~b}$ \\
Testemunha & $1,19 \mathrm{a}$ \\
& \\
D. M. S. & 0,15
\end{tabular}

${ }^{1}$ Para análise estatística os dados foram transformados segundo $\sqrt{x+0,5}$

${ }^{2}$ Médias seguidas por letras distintas diferem entre si a 5\% de significância pelo teste de Tukey.

Tabela 19. Médias de produção de biomassa seca (g/vaso) de plantas daninhas na avaliação realizada aos 30 dias após a instalação do experimento. Experimento 1 em casa de vegetação. Piracicaba, S.P. 2003 - USP/ESALQ

\begin{tabular}{cc}
\hline Plantas Daninhas & Médias \\
\hline Poaia & $0,73 \mathrm{~b}$ \\
Capim-colonião & $1,15 \mathrm{a}$ \\
Erva-palha & $1,13 \mathrm{a}$ \\
Falsa-serralha & $1,18 \mathrm{a}$ \\
Capim-colchão & $1,14 \mathrm{a}$ \\
Corda-de-viola & $1,35 \mathrm{a}$ \\
Picão-preto & $1,26 \mathrm{a}$ \\
D. M. S & 0,38
\end{tabular}

\footnotetext{
${ }^{1}$ Para análise estatística os dados foram transformados segundo $\sqrt{x+0,5}$

${ }^{2}$ Médias seguidas por letras distintas diferem entre si a 5\% de significância pelo teste de Tukey.
} 
Na Tabela 20 estão apresentadas as médias de densidade de plantas daninhas/vaso aos 30 dias após a aplicação das coberturas vegetais sobre as plantas em condições de pós-emergência (Experimento 2).

Tabela 20. Médias de densidade de plantas daninhas (plantas/vaso) na avaliação realizada aos 30 dias após a instalação do experimento. Experimento $2 \mathrm{em}$ casa de vegetação. Piracicaba, S.P. 2003 - USP/ESALQ

\begin{tabular}{cc}
\hline \multicolumn{2}{c}{ Plantas daninhas/vaso } \\
Coberturas vegetais & Médias $^{1}$ \\
Crotalária & $1,98 \mathrm{~b}$ \\
Milheto & $1,74 \mathrm{~b}$ \\
Guandu & $1,75 \mathrm{~b}$ \\
Vegetação natural & $2,15 \mathrm{~b}$ \\
Mistura de coberturas vegetais & $1,53 \mathrm{~b}$ \\
Testemunha & 3,24 a \\
& \\
D. M. S. & 0,70 \\
\hline${ }^{2}$ Para análise estatística os dados foram transformados segundo $\sqrt{x+0,5}$ & \\
${ }^{2}$ Médias seguidas por letras distintas diferem entre si a 5\% de significância pelo teste de Tukey
\end{tabular}

Analisando-se a tabela 20 pode-se perceber que todas as coberturas vegetais tiveram um controle eficaz na densidade de plantas daninhas seca quando comparadas com a testemunha. Dentre as plantas daninhas, a que apresentou uma maior densidade de plantas daninhas foi a tiririca, independentemente da cobertura vegetal (Tabela 21). 
Tabela 21. Médias de densidade de plantas daninhas (plantas/vaso) na avaliação realizada aos 30 dias após a instalação do experimento. Experimento $2 \mathrm{em}$ casa de vegetação. Piracicaba, S.P. 2003 - USP/ESALQ

\begin{tabular}{cc}
\hline Plantas daninhas & Médias $^{1}$ \\
\hline Poaia & $1,01 \mathrm{c}$ \\
Picão-preto & $1,93 \mathrm{~b}$ \\
Guanxuma & $1,37 \mathrm{c}$ \\
Tiririca & $3,01 \mathrm{a}$ \\
& \\
D. M. S. & 0,59
\end{tabular}

${ }^{1}$ Para análise estatística os dados foram transformados segundo $\sqrt{x+0,5}$

${ }^{2}$ Médias seguidas por letras distintas diferem entre si a 5\% de significância pelo teste de Tukey

Na tabela 22 estão apresentadas as médias de produção de biomassa seca de plantas daninhas para cada tipo de cobertura do experimento 2.

Tabela 22. Médias de produção de biomassa seca (g/vaso) de plantas daninhas na avaliação realizada aos 30 dias após a instalação do experimento. Experimento 2 em casa de vegetação. Piracicaba, S.P. 2003 - USP/ESALQ

\begin{tabular}{cc}
\hline Coberturas & Médias $^{1}$ \\
\hline Crotalária & $0,95 \mathrm{~b}$ \\
Milheto & $0,87 \mathrm{~b}$ \\
Guandu & $0,99 \mathrm{ab}$ \\
Capim-colonião & $0,96 \mathrm{~b}$ \\
Mistura de adubos verdes & $0,94 \mathrm{~b}$ \\
Testemunha & $1,17 \mathrm{a}$ \\
D. M. S & \\
\hline
\end{tabular}

${ }^{1}$ Para análise estatística os dados foram transformados segundo $\sqrt{x+0,5}$

${ }^{2}$ Médias seguidas por letras distintas diferem entre si a 5\% de significância pelo teste de Tukey. 
Analisando-se a Tabela 22 pode-se perceber que todas as coberturas interferiram na produção da biomassa seca quando comparadas com a testemunha, a exceção do guandu, que não apresentou diferenças significativas com a testemunha. A tiririca apresentou uma maior produção de biomassa seca, independentemente da cobertura vegetal (Tabela 23).

Tabela 23. Médias de produção de biomassa seca de plantas daninhas (g/vaso) na avaliação realizada aos 30 dias após a instalação do experimento. Experimento 2 em casa de vegetação. Piracicaba, S.P. 2003 - USP/ESALQ

\begin{tabular}{cc}
\hline Plantas daninhas & Médias $^{1}$ \\
\hline Poaia & $0,72 \mathrm{c}$ \\
Picão-preto & $0,98 \mathrm{~b}$ \\
Guanxuma & $0,72 \mathrm{c}$ \\
Tiririca & $1,36 \mathrm{a}$ \\
& \\
D. M. S. & 0,15
\end{tabular}

${ }^{1}$ Para análise estatística os dados foram transformados segundo $\sqrt{x+0,5}$

${ }^{2}$ Médias seguidas por letras distintas diferem entre si a 5\% de significância pelo teste de Tukey.

Na Tabela 24 estão apresentadas as médias de densidade de plantas daninhas/vaso aos 30 dias após a aplicação das coberturas vegetais sobre as plantas daninhas em condições de pré-emergência (Experimento 3). 
Tabela 24. Médias de densidade de plantas daninhas (plantas/vaso) na avaliação realizada aos 30 dias após a instalação do experimento. Experimento 3 em casa de vegetação. Piracicaba, S.P. 2003 - USP/ESALQ

\begin{tabular}{|c|c|c|c|c|c|}
\hline \multirow{3}{*}{$\begin{array}{l}\text { Plantas }^{1} \\
\text { Daninhas }\end{array}$} & \multicolumn{5}{|c|}{ Coberturas vegetais utilizadas } \\
\hline & Lab-lab & Guandu & Vegetação & Milheto & Testemunha \\
\hline & & anão & natural & & \\
\hline Poaia & $4,85 \mathrm{a}^{2} \mathrm{~A}$ & 3,88 aA & $1,25 \mathrm{bBC}$ & $2,11 \mathrm{bBC}$ & $3,92 \mathrm{a}$ \\
\hline Capim colonião & 2,12 abBC & $1,56 \mathrm{bBCD}$ & 2,01 abBC & $2,90 \mathrm{aAB}$ & $2,84 \mathrm{ab}$ \\
\hline Erva-palha & $1,79 \mathrm{abBC}$ & $0,71 \mathrm{bD}$ & $0,71 \mathrm{bC}$ & $2,55 \mathrm{aB}$ & $1,97 \mathrm{ab}$ \\
\hline Falsa-serralha & $2,74 \mathrm{aB}$ & 2,78 aAB & $2,09 \mathrm{aBC}$ & $1,73 \mathrm{aBC}$ & $3,02 \mathrm{a}$ \\
\hline Capim-colchão & 5,01 aA & 4,13 aA & 3,93 aA & 4,33 aA & 3,82 a \\
\hline Corda-de-viola & $2,10 \mathrm{aBC}$ & 2,68 aABC & $2,27 \mathrm{aB}$ & $2,09 \mathrm{aBC}$ & 3,35 a \\
\hline Picão preto & $1,09 \mathrm{bC}$ & $1,27 \mathrm{bCD}$ & $1,05 \mathrm{bBC}$ & $0,71 \mathrm{bC}$ & 4,05 a \\
\hline D. M. S & & 1,49 (Colunas) & & 1,30 (Linhas) & \\
\hline
\end{tabular}

Analisando-se em colunas a Tabela 24, pode-se observar o efeito isolado das coberturas vegetais sobre todas as plantas daninhas. As coberturas do lab-lab e do milheto apresentaram melhor efeito supressivo na germinação e crescimento do picãopreto que sobre as demais plantas daninhas. Enquanto, as coberturas de guandu e da vegetação natural foram eficientes sobre erva-palha quando comparadas as outras plantas daninhas analisadas.

Na mesma tabela, só que agora sendo analisadas as linhas, que refere-se ao comportamento isolado de cada planta daninha quando submetidas ao efeito de todas as coberturas vegetais, pode-se dizer que para a planta daninha poaia, a cobertura da vegetação natural e a do milheto foram as que melhor reduziram a densidade populacional desta planta daninha. Em comparação a testemunha, a cobertura da vegetação natural reduziu em 68,1\% e a do milheto em 53,8\%. 
Em relação à planta daninha capim-colonião a cobertura do guandu mostrou um efeito supressivo na redução populacional desta planta daninha. No que se refere à planta daninha erva-palha observa-se que as coberturas da vegetação natural e do guandu-anão apresentaram uma redução em comparação à testemunha em 63,9\%.

Para falsa-serralha, capim-colchão e corda-de-viola nenhuma cobertura apresentou um efeito supressivo.

Em relação ao picão-preto todas as coberturas vegetais utilizadas demonstraram efeitos significativos na redução populacional em relação a testemunha. A cobertura do milheto reduziu em 82,5\%, a do capim-colonião em 74,1\%, a do lab-lab em 73,1\% e a do guandu em $68,6 \%$.

Na Tabela 25 estão apresentadas as médias da produção da biomassa seca das plantas daninhas aos 30 dias após a aplicação das coberturas vegetais sobre as plantas daninhas em condições de pré-emergência (Experimento 3).

Tabela 25. Médias de produção de biomassa seca de plantas daninhas (g/vaso) na avaliação realizada aos 30 dias após a instalação do experimento. Experimento 1 em casa de vegetação. Piracicaba, S.P. 2003 - USP/ESALQ

\begin{tabular}{cc}
\hline Coberturas & Médias $^{1}$ \\
\hline Lab-lab & $0,97 \mathrm{a}$ \\
Guandu-anão & $0,95 \mathrm{ab}$ \\
Vegetação natural & $0,86 \mathrm{~b}$ \\
Milheto & $0,85 \mathrm{~b}$ \\
Testemunha & $1,05 \mathrm{a}$ \\
& \\
D. M. S. & 0,10
\end{tabular}

\footnotetext{
${ }^{1}$ Para análise estatística os dados foram transformados segundo $\sqrt{x+0,5}$
}

${ }^{2}$ Médias seguidas por letras distintas diferem entre si a 5\% de significância pelo teste de Tukey.

Analisando-se a Tabela 25, pode se notar que a vegetação natural e o milheto interferiram na produção de biomassa seca das plantas daninhas, quando comparadas 
com a testemunha. Dentre as plantas daninhas, as que produziram uma maior produção de biomassa seca foi a corda-de-viola e o capim-colonião (Tabela 26).

Tabela 26. Médias de produção de biomassa seca de plantas daninhas (g/vaso) na avaliação realizada aos 30 dias após a instalação do experimento. Experimento 1 em casa de vegetação. Piracicaba, S.P.2003 - USP/ESALQ

\begin{tabular}{cc}
\hline Plantas Daninhas & Médias $^{1}$ \\
\hline Poaia & $0,79 \mathrm{~cd}$ \\
Capim-colonião & $0,93 \mathrm{abc}$ \\
Erva-palha & $0,75 \mathrm{~d}$ \\
Falsa-serralha & $0,86 \mathrm{bcd}$ \\
Capim-colchão & $1,03 \mathrm{a}$ \\
Corda-de-viola & $1,00 \mathrm{ab}$ \\
Picão-preto & $0,72 \mathrm{~d}$ \\
& \\
D. M. S. & 0,15
\end{tabular}

${ }^{1}$ Para análise estatística os dados foram transformados segundo $\sqrt{x+0,5}$

${ }^{2}$ Médias seguidas por letras distintas diferem entre si a 5\% de significância pelo teste de Tukey.

Na Tabela 27 estão apresentadas as médias de densidade de plantas daninhas/vaso aos 30 dias após a aplicação das coberturas vegetais sobre as plantas daninhas em condições de pré-emergência (Experimento 4). 
Tabela 27. Médias de densidade de plantas daninhas (plantas/vaso) na avaliação realizada aos 30 dias após a instalação do experimento. Experimento 4 em casa de vegetação. Piracicaba, S.P. 2003 - USP/ESALQ

\begin{tabular}{|c|c|c|c|c|c|c|}
\hline Coberturas $^{1}$ & Crotalária & Milheto & Guandu & $\begin{array}{c}\text { Vegetação } \\
\text { Natural }\end{array}$ & $\begin{array}{c}\text { Misturas de } \\
\text { Adubos verdes }\end{array}$ & Testemunha \\
\hline Poaia & $4,50 \mathrm{a}^{2} \mathrm{~A}$ & $2,19 \mathrm{bB}$ & $1,27 \mathrm{bB}$ & $1,17 \mathrm{bB}$ & $1,54 \mathrm{bAB}$ & 3,93 a \\
\hline Picão-preto & $1,27 \mathrm{bC}$ & $0,88 \mathrm{bC}$ & $1,05 \mathrm{bB}$ & $0,71 \mathrm{bB}$ & $0,71 \mathrm{bB}$ & 3,85 a \\
\hline Guanxuma & $0,71 \mathrm{bC}$ & $0,88 \mathrm{bC}$ & $0,71 \mathrm{bB}$ & $0,71 \mathrm{bB}$ & $0,71 \mathrm{bB}$ & $2,91 \mathrm{a}$ \\
\hline Tiririca & $3,23 \mathrm{aB}$ & $3,54 \mathrm{aA}$ & $2,61 \mathrm{aA}$ & 2,71 aA & 2,48 aA & $3,72 \mathrm{a}$ \\
\hline D. M. S. & & 1,10 (Co & lunas) & & 1,17 (Linhas) & \\
\hline
\end{tabular}

Analisando-se a Tabela 27 em colunas pode-se notar que a crotalária foi mais eficiente na supressão da infestação de guanxuma. O milheto teve maior eficiência em guanxuma e em picão-preto. O guandu e a vegetação natural apresentaram uma melhor supressão na guanxuma, picão-preto e poaia. A cobertura das misturas de adubos verdes em guanxuma e picão preto. Ainda na tabela 27, agora sendo analisadas as linhas, pode se observar que, para a planta daninha poaia, o melhor controle foi obtido com as coberturas da vegetação natural, guandu, a mistura de adubos verdes e o milheto. Comparando estas coberturas com a testemunha, a cobertura da vegetação natural reduziu em $70,2 \%$, o guandu em $67,7 \%$, a mistura em $60,5 \%$ e o milheto em $32,4 \%$.

Em relação ao picão-preto, observa-se que todas as coberturas tiveram uma redução satisfatória desta planta daninha. Comparando-se com a testemunha, as coberturas da vegetação natural e a mistura de coberturas tiveram uma redução de $81,5 \%$, o milheto em $77,1 \%$, o guandu em $72,7 \%$ e a crotalária em $67,1 \%$.

Os quatro resíduos vegetais suprimiram com eficiência a guanxuma. Em comparação com a testemunha, observa-se que houve uma redução de 75,6\%, a exceção da milheto que reduziu em $69,7 \%$. 
Para a planta daninha tiririca não houve diferenças entre as coberturas utilizadas e a testemunha.

Na tabela 28, estão apresentadas as médias de produção de biomassa seca de plantas daninhas/vaso aos 30 dias após a aplicação das coberturas vegetais sobre as plantas daninhas em condições de pré-emergência (Experimento 4).

Tabela 28. Médias de produção de biomassa seca de plantas daninhas (g/vaso) na avaliação realizada aos 30 dias após a instalação do experimento. Experimento em casa de vegetação. Piracicaba, S.P. 2003 - USP/ESALQ

\begin{tabular}{ccccccc}
\hline Coberturas $^{1}$ & Crotalária & Milheto & Guandu & $\begin{array}{c}\text { Vegetação } \\
\text { Natural }\end{array}$ & $\begin{array}{c}\text { Misturas de } \\
\text { Adubos verdes }\end{array}$ & Testemunha \\
& & & & $0,71 \mathrm{bB}$ & $0,74 \mathrm{abB}$ & $1,01 \mathrm{ab}$ \\
Poaia & $0,94 \mathrm{a}^{2} \mathrm{~B}$ & $0,73 \mathrm{abB}$ & $0,71 \mathrm{bB}$ & $0,71 \mathrm{aB}$ & $0,78 \mathrm{a}$ \\
Picão-preto & $0,74 \mathrm{aBC}$ & $0,72 \mathrm{aB}$ & $0,72 \mathrm{aB}$ & $0,71 \mathrm{aB}$ & $0,71 \mathrm{aB}$ & $0,72 \mathrm{a}$ \\
Tiririca & $1,83 \mathrm{aA}$ & $1,38 \mathrm{bA}$ & $1,35 \mathrm{abA}$ & $1,26 \mathrm{bcA}$ & $1,40 \mathrm{bA}$ & $1,20 \mathrm{bc}$ \\
& & & & & & \\
D. M. S & 0,19 (Colunas) & & & $0,71 \mathrm{aB}$ & \\
\hline
\end{tabular}

${ }^{1}$ Para análise estatística os dados foram transformados segundo $\sqrt{x+0,5}$

${ }^{2}$ Médias seguidas por letras distintas minúsculas na linha e maiúsculas na coluna diferem entre si a $5 \%$ de significância pelo teste de Tukey.

Analisando-se a Tabela 28, em colunas, verifica-se que as diferentes coberturas interferiram de forma igual na produção de biomassa seca da guanxuma, picão-preto, poaia. Enquanto que para tiririca nenhuma cobertura mostrou um efeito na produção de biomassa seca.

Analisando-se em linhas, a Tabela 28, pode-se notar que, em relação à planta daninha poaia, o melhor efeito foi com o guandu e a vegetação natural. Para o picãopreto e para guanxuma, nenhuma cobertura apresentou um efeito na produção da biomassa seca dessas plantas daninhas. Para tiririca também não houve efeito significativo das coberturas. 


\section{CONCLUSÕES}

Pelos dados obtidos nas condições locais dos experimentos conduzidos pode-se concluir que:

a) No pomar em produção a cobertura com vegetação natural apresentou o melhor efeito supressivo sobre as plantas daninhas.

b) A adubação am área total, independentemente da cobertura vegetal utilizada apresentou uma menor densidade de plantas daninhas nas linhas das plantas cítricas.

c) A adubação em área total aumentou os teores de matéria orgânica e potássio

d) O lab-lab foi a cobertura que apresentou maior concentração de cálcio na profundidade de $10-20 \mathrm{~cm}$.

e) No pomar em formação as coberturas formadas pela vegetação natural e a mistura de adubos verdes apresentaram os melhores efeitos supressivos em relação às plantas daninhas presentes na área experimental. 
f) Em condições de casa de vegetação a cobertura da vegetação natural apresentou, de forma geral, maior eficiência na supressão de todas as plantas daninhas em estudo, tanto em condições de pós-emergência como de pré- emergência.

A utilização de adubos verdes pode contribuir de maneira significativa na redução da comunidade infestante, auxiliando de forma sustentável o manejo integrado de plantas daninhas, além de contribuir com outros benefícios inerentes a utilização dessa prática. 


\section{REFERENCIAS BIBLIOGRAFICAS}

ABECITRUS. Exportações série histórica. www.abecitrus.com.br. (7 mar. 2003)

ADEGAS, F.S. Manejo integrado de plantas daninhas. Plantio direto, v.40, p.17-21, jul./agost. 1997.

ALMEIDA, F.S. A alelopatia e as plantas. Londrina: IAPAR, 1988. 60 p.

ALVES, P.L. da C.A.; PITELLI, R.A. Manejo ecológico de plantas daninhas. Informe Agropecuário, v.22, n. 212, p.29-39, set./out. 2001.

AMARO, A.A.; ARÁUJO, C.M.; PORTO, O.M.; DORNELLES, C.M.M.; CUNHA SOOBRINHO, A.P.C.; PASSOS, O.S. Panorama da citricultura brasileira. In: RODRIGUEZ, Z.O.; VIÉGAS, F.C.P.; POMPEU JUNIOR, J.; AMARO, A.A. (Ed). Citricultura Brasileira. São Paulo: Fundação Cargill, 1991. v.1, p.22-59.

AMARO, A.A.; MAIA, M.L. Produção e comércio de laranja e de suco no Brasil. Informações Econômicas, v.27, n.7, p.11-23, 1997.

ANDRADE, B.L.A.; ABRAHÃO, M.J.T.; GODOY, P.O. Efeitos da incorporação de Crotalaria juncea L. sobre algumas características do solo e do desenvolvimento inicial da cana-de-açúcar (Saccharum spp.). Adubação verde no Brasil. Campinas: Fundação Cargill, 1984, p.46-47. 
BLANCO, H.G. A importância dos estudos ecológicos nos programas de controle de plantas daninhas. Biológico, v.38, n.10, p.343-350, 1972.

BLANCO, H.G.; OLIVEIRA, D.A. Estudos dos efeitos da época de controle do mato sobre a produção de citrus e a decomposição da flora daninha. Arquivos do Instituto Biológico, v.45, p.25-36, 1978.

BLEASDALE, J.K.A. Studies on plant competition. In: HARPER, J.L. (Ed.) The biology of weeds. Oxford: Blackwell Scientific, 1960. p.133-142.

BORTOLAZZO, E.D. Efeitos da área de controle das plantas daninhas (coroamento ou faixa) no desenvolvimento inicial da tangerina 'poncã' (Citrus reticulata Blanco). Piracicaba, 2002. 77p. Dissertação (Mestrado) - Escola Superior de Agricultura “Luiz de Queiroz”, Universidade de São Paulo.

BRUCE, R.R; HENDRIX, P.F.; LANGDALE, G.W. Role of cover crops in recovery and maintenance of soil productivity. COVER CROPS FOR CLEAN WATER. IN: INTERNATIONAL CONFERENCE. WEST JACKSON, TENNESSE, 1991. Proceedings Jackson, TE: April 9- 11. Jackson, Tennessee. WSCS. 1991.v.1.

BUCKLE, D. El frijol terciopelo: una planta "nueva" con historia. CIMMYT Documental Interno. México CIMMYT. 1992. 26p.

CABRERA, D.R.A. Manejo para produção sustentável de citros: hipóteses de trabalho e resultados preliminares (Compact disc) In: SIMPÓSIO SOBRE FISIOLOGIA, NUTRIÇÃO, ADUBAÇÃO E MANEJO SUSTENTÁVEL DE CITROS. Anais. Piracicaba, S. P: POTAFOS, 2000. 
CABRERA, D.R.A.; YAMADA, T. Manejo da fertilidade do solo e da adubação na convivência com pragas e doenças dos citros (Compact disc) In: RELAÇÃO ENTRE NUTRIÇÃO DE PLANTAS E INCIDÊNCIA DE DOENÇAS. Anais. Piracicaba, S.P: POTAFOS, 2002.

CAETANO, A.A. Herbicidas em citros. In: RODRIGUEZ, O.; VIEGAS, F. Citricultura Brasileira. São Paulo: Fundação Cargill, 1980. p.445-466.

CAETANO, R.S.X.; CHRISTOFFOLETI, J.J.; VICTORIA FILHO, R. Banco de sementes de plantas daninhas em pomar de laranjeira 'Pêra'. Scientia Agricola, v.58, n.3, p.509-517, 2001.

CAMARGO, T.L.A.; HERMANN, J. Contribuição para o estudo da adubação verde das terras roxas cansadas. Campinas: Instituto Agronômico, 1928. 22p. (Boletim Técnico, 1).

CARVALHO, J.E.B.; CALDAS, R.C.; CARDOSO, S.S.; COSTA NETO, A.O. Influência das épocas de controle das plantas daninhas na produção de laranja 'Pêra'. Planta Daninha, v.11, n.1/2, p.49-54, 1993.

CARVALHO, J.E.B.; PAES, J.M.V.; MENEGUCCI, J.L.P. Manejo de plantas daninhas em citros. Informe Agropecuário. v.22, n.209, p.1661-1670, 2001.

CARVALHO, J.E.B.; SOUZA, L.S.; CALDAS, R.C.; ANTAS, P.E.U.T.; ARÁUJO, A.M.A.; LOPES, L.C.; SANTOS, R.C.; LOPES, N.C.; SOUZA, A.L.V. Leguminosa no controle integrado de plantas daninhas para aumentar a produtividade da laranja 'Pêra'. Revista Brasileira de Fruticultura, v.24, n.1, p.82-85, 2002. 
CARVALHO, J.E.B.; SOUZA, L.S.; RAMOS, W.F.; LOPES, L.C.; ARÁUJO, A.M.A. Manejo do solo e cobertura vegetal em citros na Bahia e em Sergipe. Laranja, v.22, n.1, p.271-284, 2001.

CASAMAYOR, R. Influencia de la competencia de las plantas indeseables sobre los rendimientos del naranjo Valencia Latte. In: SIMPOSIO DE CITRICULTURA TROPICAL. La Habana Cuba, 1986. Memorias. La Habana. v.2, p.159-167.

CHAGAS, M.J.; VIEIRA, F.R.; ARAUJO, A.G.A. de.; ARAUJO, P.J.P. de. Efeitos da incorporação da Crotalaria juncea sobre a cultura do feijão no cerrado. Revista Ceres, v.34, n.192, p.152-161, 1987.

CHAVES, J.C.D. Efeito de adubações mineral, orgânica e verde sobre a fertilidade do solo, nutrição e produção do cafeeiro. In: SIMPOSIO DE PESQUISA DOS CAFES DO BRASIL, 1., Poços de Caldas, 2000. Resumos expandidos. Brasília: Embrapa Café, 2000. v.2. p.1389-1392.

CHAVES, J.C.D.; CALEGARI, A. Adubação verde e rotação de culturas. Informe Agropecuário, v.22, n.212, p.53-60, set./out. 2001.

CHAVES, J.C.D.; GORRETA, R.H.; DEMONER, C.A.; CASANOVA JUNIOR, G.; FANTIN, D. O amendoim cavalo (Arachis hypogaea) como alternativa para cultivo intercalar em lavoura cafeeira. Londrina: IAPAR, 1997. 20p. (IAPAR. Boletim Técnico, 55).

CHIAVEgATO, L.G. Biologia do acaro Brevipalpus phoenicis em Citrus. Pesquisa Agropecuária Brasileira, v.21, n.8, p.813-816, 1986. 
CINTRA, P.L.D.; MIELNICZUK, J. Potencial de algumas espécies vegetais para a recuperação de solos com propriedades físicas degradadas. Revista Brasileira de Ciência do Solo, v.7, p.190-201, 1983.

CLARKSON, D.T. Adaptações morfológicas e fisiológicas das plantas a ambientes de baixa fertilidade. In: SIMPOSIO SOBRE RECICLAGEM DE NUTRIENTES E AGRICULTURA DE BAIXOS INSUMOS NOS TROPICOS. Ilhéus, 1985. Reunião Brasileira de Fertilidade do solo, v.16, p.45-47, 1985.

COSTA, M.B.B. Adubação orgânica: nova síntese e novo cambio para a agricultura. São Paulo: Ícone, 1989. 107p (Coleção Brasil Agrícola).

COSTA, M.B.B; CALEGARI, A.; MONDARD, A.; BULISANI, E.A.; WILDNER, L.P.; ALCÂNTARA, P.B.; MIYASAKA, S.; AMADO, T.J.C. Adubação verde no sul do Brasil. 2. ed. Rio de Janeiro: AS-PTA, 1993. 346p.

DAVIES, F.; ALBRIGO, L. Citrus. Wallinford: CAB International, 1994, 245 p.

DE NEGRI, J.D. Cultura do citrus. Campinas: CATI, 1996. 35p. (Boletim técnico da coordenadora de assistência técnica integral, 228).

DERPSCH, R. Adubação verde, Rio de janeiro: SAI, 1985. 42p.

DERPSCH, R.; SIDIRAS, N.; HEINZMANN, F.X. Manejo do solo com coberturas verdes de inverno. Pesquisa Agropecuária Brasileira, v.20, n.7, p.761-773, 1985.

DOMINGUEZ, V.J.A. Las coberturas vivas y el control de malezas. Acapulco: Colegio Superior Agropecuario del Edo. de Guerrero, Asosiación Mexicana de la Ciencia de la Maleza. Acapulco Guerrero. 1991, p. 86-98. 
DOMINGUEZ, V.J.A.; MEDINA, P.J. Cultivos de cobertura indispensables para uma agricultura sustentable. Revista Mexicana de la Ciência de la Maleza. n.1, p.36-45, 2000 .

DURIGAN, J.C. Controle químico de plantas daninhas na citricultura. Jaboticabal: Funep/Fcav - UNESP, 1988. 17p.

DURIGAN, J.C. Controle químico de plantas daninhas na citricultura. Laranja, v.15, n.12, p.277-293, 1994.

DURIGAN, J. C. Controle do Mato: produção sem perdas. Fundecitrus. v.78, p.12, 1996.

EINHELLIG, F.A. Mechanism and modes of action of allelochemicals. In: PUTNAM. A.R.; TANG, C.S. (Ed.). The science of allelopathy. New York: John Wiley, 1986. p.171-188.

FAO. FAOSTAT: STATISTICS DATABASE. http://apps.fao.org (6 jan. 2004)

FÁVERO, C.; JUCKSCH, I. Daninhas ou companheiras? Boletim Informativo [da] Sociedade Brasileira de Ciência do Solo, v.25, n.2, p.26-27, abr./jun. 2000.

FERNANDEZ, M.F.; BARRETO, A.C.; EMIDIO FILHO, J. Fitomassa de adubos verdes e controle de plantas daninhas em diferentes densidades populacionais de leguminosas. Aracaju. SE. Pesquisa Agropecuária Brasileira. v.34, n.9, p.15931600, 1999. 
FNP CONSULTORIA \& COMÉRCIO. Agrianual 2003: anuário estatístico da Agricultura brasileira. São Paulo, 2003. p.295-315.

FRANCO, A.A.; SOUTO, S.M. Contribuição da fixação biológica de $\mathrm{N}_{2}$ na adubação verde. Adubação verde no Brasil. Campinas: Fundação Cargill, 1984. p.199-215.

GELMINI, G.A. Herbicidas: Indicações básicas.Campinas: Fundação Cargill, 1988. 334p.

GLORIA, N.A. da; MATTIAZO, M.E.; PEREIRA, V.; PARO, J.M. Avaliação da produção de adubos verdes. Saccharum, v.3, n.8, p.31-35, 1980.

GRANER, E.A.; GODOY JUNIOR, C. Culturas da fazenda brasileira. 4 ed. São Paulo: Melhoramentos, 1967. p.19-461.

GRODZINSKY, M.A. Allelopathic effects of cruciferous plants in crop rotation. In: RIZVI, S. J. H.; RIZVI, V. (Ed.). Alleopathy - basis and applied aspects. New York: Chaman \& Hall, 1992. p.77-84.

GUSTAFSON, A.F. Soils and soil management. New York: Mac-Graw-Hill, 1941. 424p.

HEINZMANN, F.X. Mineralização dos resíduos das culturas de inverno e assimilação de nitrogênio pelas culturas de verão sob plantio direto. In: CONGRESSO BRASILEIRO DE CIÊNCIA DO SOLO. Curitiba: Sociedade brasileira de ciência do solo, 1983. p.59.

HOROWITZ, M. Competitive effects of Cynodon dactilon, Sorghum halepense and Cyperus rotundus on cotton and mustard. Experimental Agriculture, v.9, n.3, p.263-273, 1973. 
IGUE, K. Dinâmica da matéria orgânica e seus efeitos nas propriedades do solo. In: FUNDAÇÃO CARGILL. Adubação verde no Brasil. Campinas: Fundação Cargill: 1984. p.232-267.

INSTITUTO AGRONÔMICO DO PARANA. A citricultura no Paraná. Londrina: IAPAR, 1992. 96p. (IAPAR, Documentos, 9).

INSTITUTO AGRONÔMICO DO PARANA. Guia de adubação verde de inverno. Londrina, 1985. 288p. (IAPAR, Circular, 72).

JARILLO, M.A. Leguminosas de cobertura para el control de malezas en naranjo (Citrus sinensis (L.) Osbeck) en la region de Martínez de la Torre, Veracruz. Chapingo, Méx. 1994. 40p. Tese (Graduación), Universidad Autonoma Chapingo.

JONES, W.W.; EMBLETON, T.W. Soils, soil management and cover crops. In: REUTHER, W., BATCHELOR, L.D., WEBBER, H.J. The citrus industry. Berkeley, University of California, Division of Agricultural Sciences, 1973. v.3, p.98-121.

JORDAN, L.S. Weeds affect citrus growth, physiology, yeld, fruit quality. Proceedings of the International Society of Citriculture, v.2, p.481-483, 1983. / Resumo em CAB Abstract on CD-ROM, 1987-1989/

KLUTHCOUSKI, J. Leucaena: alternativa para pequena e média agricultura. Goiânia: EMBRAPA-CNPAF, 1980. 23p. (Circular técnica, 6). 
KOLLER, O.C. Citricultura: laranja, limão e tangerina. Porto Alegre: Editora Rigel, 1994. 446p.

LEITE JÚNIOR, R.P.; MOHAN, S.K. Integrated management of citrus bacterial canker disease caused by Xanthomonas campestris pv. citri in the State of Paraná, Brazil. Crop protection, v.9, p.3-7, 1990.

LYNCH, J.M. Biotecnologia do solo. São Paulo: Ed. Manole, 1986. 209p.

MALAVOLTA, E. Manual de química agrícola: nutrição de plantas e fertilidade do solo. São Paulo: Editora Agronômica Ceres, 1976. 528p.

MARTIN, J.P.; WAKSMAN, S.A. Influence of microorganisms on soil aggregation an erosion II. Soil Science, v.52, p.381-394, 1941.

MELLO, F.A.F. Fertilidade do solo. 3 ed. São Paulo: Nobel, 1988, 400p.

MENEGUCCI, J.L.P.; AMARAL, A.M. do; SOUZA, M. de. Alterações das propriedades químicas do solo na camada subsuperficial após adubação verde com crotalária. Revista Brasileira de Fruticultura, v.17, n.3, p.7-12, 1995.

MIYAZAWA, M.; PAVAN, M.A.; CALEGARI, A. Efeito de material vegetal na acidez do solo. Revista Brasileira de Ciência do Solo, v.17, n.3, p.411-416, set./dez, 1993.

MUZILli, O.; OLIVEIRA, E.D. de; CALEGARI, A. Adubação do milho. Campinas: Fundação Cargill, 1989. 29 p. (Série Técnica, 4). 
NEME, N.A. Leguminosas para adubos verdes e forragens. Campinas: Instituto Agronômico, 1959, v.1 (IAC. Boletim Técnico).

NEVES, C.S.V.J.; DECHEN. A.R.; FELLER, C.; GONZALEZ, M.G.N. Influência de sistemas de manejo de solo em pomar de tangerina 'Ponca' sobre limão 'Cravo' em latossolo roxo. Revista Brasileira de Fruticultura, v.20, n.3, p.367-374, 1998.

NEVES, E.M.; BOTEON, M. Impactos alocativos e distributivos na citricultura. Preços Agrícolas, n.136, p.3-6, 1998.

NEVES, E.M.A. Competitividade da Agroindústria citrícola brasileira: vantagens comparativas e o dilema das barreiras comerciais. Piracicaba: ESALQ, 1996. 125 p. (Relatório de Pesquisa para CNPq).

PAVAN, M.A.; CARAMORI, P.H.; ANDROCIOLI FILHO, A.; SCHOLZ, M.F. Manejo da cobertura do solo para formação e produção de uma lavoura cafeeira - I: influencia na fertilidade do solo. Pesquisa Agropecuária Brasileira, v.21, n.2, p. 187-192, fev. 1986.

PAVAN, M.A.; CHAVES, J.C.D. A importância da matéria orgânica nos sistemas agrícolas. Londrina: IAPAR, 1998. 36p. (IAPAR. Circular, 98).

PEREZ, E.; LABRADA, R. Umbrales de daños de Cynodon dactylon en cítricos de fomento. Agrotecnica de Cuba, v.18, n.1, p.75-81, 1986.

PETTO NETO, A. Práticas culturais In: RODRIGUEZ, O; VIEGAS F; POMPEU JÚNIOR. J. Citricultura Brasileira. Campinas: Fundação Cargill, 1991, p.476-490.

PITELLI, R.A. Interferência de plantas daninhas em culturas agrícolas. Informe Agropecuário. v.11, n.129, p. 16-27, 1985. 
PRATES, H.T; PIRES, N. de M.; PEREIRA FILHO, I.A.; MAGALHÃES, P.C. Utilização da leucena como fonte alternativa de controle natural das plantas daninhas na cultura do milho. Plantio Direto, v.67, p.29-68, 2000.

PRICE, M. Necesidades de informaciones para el uso de mucuna como alimento concentrado, expresado para organizaciones dedesarrollo. In: TALLER: MUCUNA COMO ALIMENTO Y CONCENTRADOS: USOS ACTUALES Y EL CAMINO POR DELANTE. Tegucigalpa: Fundação Rockefeller, 1997. Resumenes. Tegucigalpa, Honduras, 1997. www.cidicco.hn/memoria-del taller-de mucuna (12 agosto 2003)

PROEBSTING, E.L. Some effects of long continued cover cropping in a California orchard. Proceeding of the American Society for Horticultural Science, v.60, p.87-90, 1952.

RIZVI, S.J.H.; RIZVI, V. Allelopathy - basic and apllied aspects. New York: Chapman \& Hall, 1992. 479 p.

RODRIGUES, O. Aspectos fisiológicos, nutrição e adubação dos citros. In: RODRIGUES, O.; VIÉGAS, F.; POMPEU JÚNIOR, J.; AMARO, A.S. Citricultura brasileira. Campinas: Fundação Cargill, 1991. v.1, p.419-475.

RUPPER, G. Cultivation of marejea (Crotalaria ochrolecua): The experience of Peramiho. In: WRITERS' WORKSCHOP ON THE ROLE OF MAREJEA (Crotalaria ochroleuca) IN AGRICULTURAL PRODUCTION IN TANZANIA, Paramiho, 1986, 1987. Proceedings, edited by A. N. Minjas et al. Paramiho: Benedictine Public. Ndanda Peramiho, 1987. p 9-12. 
SANCHES, A.C. Conservação do solo em pomares cítricos. In: SEMINARIO INTERNACIONAL DE CITROS - TRATOS CULTURAIS 5., Bebedouro, 1998. Anais. Bebedouro: Fundação Cargill, 1998. p.167-187.

SÃO JOSÉ, A.R. Efeitos de métodos de controle de plantas daninhas na formação de pomar de laranjeira ‘Hamlin’ (Citrus sinensis (L.) Osbeck). Jaboticabal, 1988, 117 p. Tese (Doutorado) - Faculdade de Ciências Agrárias e Veterinárias, Universidade Estadual Paulista “Julio de Mesquita Filho”.

SCARANARI, H.J.; INFORZATO, R. Sistema radicular das principias leguminosas empregadas como adubo verde em cafezal. Bragantia, v.12, n.7/9, p.291-297, 1952.

SEVERINO, F.J. Adubação verde: Efeitos supressivos sobre a infestação de plantas daninhas e seletividade de herbicidas. Piracicaba, 2000. Dissertação (Mestrado) 120p. Escola Superior de Agricultura “Luiz de Queiroz”, Universidade de São Paulo.

SILVA, F.T.; CHAVES, R.N.M. Estudo sobre recuperação de solos e competição de leguminosas na produção de milho. Agronomia, v.24, p.23-28, 1966.

SILVA, J.A.A. Consorciação de adubos verdes na cultura de citros em formação. Piracicaba, 1995. 116p. Dissertação (Mestrado) Escola Superior de Agricultura “Luiz de Queiroz”, Universidade de São Paulo.

SILVA, J.A.A.; DONADIO, L.C.; CARLOS, J.A.D. Adubação verde em citros. UNESP/FUNEP/EECB. 1999, 37p. (Boletim Citrícola.).

SINGH, M.; ACHHIREDDY, N.R. Influence of Lantana on growth of various citrus rootstooks. Hortscience, v.22, n.3, p.385-386, 1987. 
SKORA, NETO, F. Controle de plantas daninhas através de coberturas verdes consorciadas com milho. Pesquisa Agropecuária Brasileira. v.28, n.10, p.11651171, 1993.

TEASDALE, J.R.; DAUGHTRY, C.S.T. Weed suppression by live and desiccated hairy vetch. WEED SCIENCE, v.41, p.207-212, 1993.

TEIXEIRA, L.A.J. Fornecimento de nitrogênio ao milho por sistemas de culturas. Porto Alegre, 1988. 96p. Dissertação (Mestrado). Universidade Federal do Rio Grande do Sul.

TERSI, F.E.A. Avaliação de métodos de manejo do solo e de plantas daninhas em um pomar de laranja Valência. Jaboticabal, 2001, 78p. Tese (Doutorado) - Faculdade de Ciências Agrárias e Veterinárias, Universidade Estadual Paulista "Julio de Mesquita Filho".

TERSI, F.E.A.; SOUZA, E.C.A.; RIGOLIN, A.Y. Efeito de métodos de manejo de plantas daninhas em crescimento, produtividade, qualidade do suco e estado nutricional de um pomar cítrico. Laranja, v.20, n.1, p.119-133, 1999.

THOMSON, L.M. Soils and fertility. New York: Mc Graw-Hill, 1952. 339p.

TISDALE, S.L.; NELSON, W.L.. Soil fertility and fertilizers. New York: Mcmillan Publishing, 1975. 645p.

TOUSSON, T.A. Nature of phytotoxic substances during plant residue decomposition in soil. Phytopatologie, v.58, p.41-45, 1968. 
VICTORIA FILHO, R. Efeitos do uso continuo de herbicidas no desenvolvimento, produção e qualidade dos frutos de dois cultivares de citros (Citrus sinensis (L.) Osbeck). Piracicaba, 1983. 232p. Tese (Livre Docência) Escola Superior de Agricultura “Luiz de Queiroz”, Universidade de São Paulo.

VICTORIA FILHO, R. Manejo de plantas daninhas em citros no Brasil. In: SEMINÁRIO INTERNACIONAL DE CITROS - TRATOS CULTURAIS, 5., Bebedouro, 1998. Anais. Bebedouro: Fundação Cargill, 1998. p.357-376.

VICTORIA FILHO, R.; MOREIRA, C.S.; SHIMOAMA, N.Y.; SHINOARA, R.K. Uso continuo de herbicidas em citrus (Citrus sinensis (L.) OSBECK). II - Efeitos no desenvolvimento, produção e qualidade dos frutos. Planta Daninha, v.9, n.1/2, p.102-113, 1991.

VIDAL, T.P.; SPAROVECK, G. Mapa pedológico escala 1:10000 detalhado do campus "Luiz de Queiroz", Universidade de São Paulo, Piracicaba, S.P. 1993 (Não publicado).

VIÉGAS, F.C.P.; GUIMARÃES, J.A.B. Citrus fruit for processing in Brazil. IN: INTERNATIONAL CONGRESS OF FRUIT JUICE, 11., São Paulo, 1991. Anais São Paulo: 1991. p.1-27.

VITTI, G.C.; FERREIRA, M.E.; PERECIN, D.; ZANETTI NETO, P. Influencia de cinco leguminosas, como adubação verde, na fertilidade de um Latossol Vermelho Amarelo-fase arenosa (LVa). Cientifica, v.7, n.3, p.431-435, 1979. 
YAMADA, T. Manejo da matéria orgânica e da adubação boratada para produção sustentável de citros: Hipóteses de trabalho e resultados preliminares (Compact disc.). In: SIMPÓSIO SOBRE FISIOLOGIA, NUTRIÇÃO, ADUBAÇÃO E MANEJO SUSTENTÁVEL DE CITROS. Anais. Piracicaba, S. P. 2000. Piracicaba: POTAFOS. 2000. 